\title{
Grouping of Plant-Pathogenic and Some Other Pseudomonas spp. by Using Cellular Fatty Acid Profiles
}

\author{
D. E. STEAD \\ National Collection of Plant Pathogenic Bacteria, Ministry of Agriculture, Fisheries and Food, \\ Central Science Laboratory, Harpenden, Hertfordshire AL5 2BD, United Kingdom
}

\begin{abstract}
Approximately 500 fatty acid profiles were prepared for 340 strains of plant-pathogenic and other bacteria currently or recently classified in the genus Pseudomonas Migula 1984. Strains representing some infraspecific taxa were included. The fatty acid profiles were stable and reproducible provided that cultural and chemical techniques were standardized. The 2- and 3-hydroxy fatty acids were found to be useful in grouping strains into six major groups, several of which were further differentiated into subgroups. Group 1 contained strains of the following species and subspecies: Pseudomonas aeruginosa, $P$. agarici, $P$. asplenii, $P$. aureofaciens, $P$. caricapapayae, P. chlororaphis, P. cichorii, P. ficuserectae, P. fluorescens, $P$. fuscovaginae, "P. gingeri," $P$. marginalis, $P$. meliae, $P$. putida, “ $P$. reactans," $P$. syringae, $P$. tolaasii, and $P$. viridiflava (subgroup 1 a); $P$. corrugata (subgroup 1b); $P$. rubrisubalbicans (subgroup 1c); $P$. alcaligenes, $P$. pseudoalcaligenes subsp. pseudoalcaligenes, and $P$. stutzeri (subgroup 1d); $P$. amygdali (subgroup 1e); and $P$. cattleyae NCPPB 1874 (subgroup 1f). All group 1 strains contained 10:0 3-OH and 12:0 3-OH, and most group 1 strains also contained 12:0 2-OH. Group 2 contained strains belonging to the following taxa: $P$. andropogonis, $P$. caryophylli, $P$. cepacia, $P$. gladioli, $P$. plantarii, and $P$. glumae (in part) (subgroup 2a); $P$. glumae (in part) (subgroup 2b); and $P$. solanacearum, $P$. syzygii, and the banana blood disease bacterium (subgroup 2c). All of the group 2 strains contained 14:0 3-OH, 16:0 3-OH, and 18:1 2-OH; most also contained 16:1 2-OH and 16:0 2-OH. Group 3 contained strains belonging to the following taxa: Comamonas acidovorans, $P$. avenae, $P$. cattleyae NCPPB 961, $P$. pseudoalcaligenes subsp. citrulli, $P$. pseudoalcaligenes subsp. konjaci, $P$. rubrilineans (subgroup 3a); and Comamonas testosteroni (subgroup 3b). All of the group 3 strains contained 10:0 3-OH. The group 4 strains were members of Sphingomonas paucimobilis, and all contained only 14:0 2-OH. The group 5 strains were members of $P$. flectens and contained 12:0 2-OH, 14:0 2-OH, and 14:0 3-OH. The group 6 strains were $P$. betle, $P$. cissicola, $P$. hibiscicola, Xanthomonas maltophilia, and Xanthomonas campestris pv. campestris strains, and all contained 12:0 3-OH, 11:0 iso 3-OH, and 13:0 iso 3-OH. Within each group or subgroup, qualitative and quantitative differences in profiles occurred for most species. Differences were also found at the infraspecific level for some taxa. My results support genomic and other data which show that the plant-pathogenic and other pseudomonads tested should be placed in at least six genera.
\end{abstract}

A total of 86 species were included in the genus Pseudomonas Migula 1894 on the Approved Lists of Bacterial Names (25). Bradbury (1) listed 32 of these species that contain plant pathogens. DNA-DNA and DNA-rRNA homology studies have been useful in classifying some of these species, and Palleroni and coworkers (17-19) have proposed five rRNA subgroups, which center around the following species: Pseudomonas aeruginosa, $P$. solanacearum, $P$. acidovorans, $P$. diminuta, and $P$. maltophilia. This proposal has been supported by the results of other independent work, which has grouped these bacteria into similar subdivisions $(4,5,7)$ by using rRNA cistron similarity data. These groupings have also been supported by the results of studies in which enzyme techniques were used $(2,32)$. More recently, cellular fatty acid profiles have been used to classify some Pseudomonas spp. $(8,16)$. The results of these studies have indicated that each of the major rRNA subgroups has a characteristic fatty acid profile in which the hydroxy acids are of particular taxonomic value.

Members of two of the rRNA subgroups have been reclassified in other genera. $P$. maltophilia (rRNA group V) has been reclassified as Xanthomonas maltophilia (29). $P$. acidovorans and $P$. testosteroni (rRNA group III) have recently been reclassified in the genus Comamonas (6) as Comamonas acidovorans and Comamonas testosteroni, respectively (30). In addition, $P$. paucimobilis has been reclassified as Sphingomonas paucimobilis (35).
In this study I wanted to determine whether the plantpathogenic pseudomonads can be classified on the basis of fatty acid profiles. I hoped that a classification based on fatty acid profiles which allowed differentiation of taxa at least at the specific level might form the basis of a future rapid, accurate identification method.

All of the bacteria used in this study fall under the definition of the genus Pseudomonas Migula 1894. Recent nomenclatural changes were taken into account where appropriate. Some infraspecific taxa and some recently described and invalidly named Pseudomonas species were also included.

\section{MATERIALS AND METHODS}

Bacterial cultures. All of the cultures were obtained from the National Collection of Plant Pathogenic Bacteria (NCPPB) and from recent diagnoses unless stated otherwise. Information on the strains used is shown in Table 1 . All of the strains except the $P$. amygdali, and $P$. syzygii strains and the banana blood disease bacterium strains were grown aerobically on Trypticase soy agar (Trypticase soy broth [BBL] containing Bacto Agar [Difco]) at $28^{\circ} \mathrm{C}$ for $24 \pm 1 \mathrm{~h}$. $P$. amygdali strains were grown on nutrient dextrose agar (CM3 nutrient agar [Oxoid] containing 1\% glucose) for 7 days at $28^{\circ} \mathrm{C}$. $P$. syzygii strains were grown on casein salts agar $(7.5 \mathrm{~g}$ of acid casein hydrolysate [Oxoid], $2.0 \mathrm{~g}$ of 
TABLE 1. Strains used

\begin{tabular}{|c|c|c|}
\hline Bacterium (synonym[s]) & $\begin{array}{l}\text { No. of } \\
\text { GC runs }\end{array}$ & $\operatorname{Strain}(\mathbf{s})^{a}$ \\
\hline $\begin{array}{l}\text { C. acidovorans (den Dooren de Jong 1926) Tamaoka et al. } \\
1987 \text { (P. acidovorans den Dooren de Jong 1926, } P \text {. } \\
\text { desmolytica Gray and Thornton } 1928)^{b}\end{array}$ & 3 & NCPPB 1967, NCPPB 1968 \\
\hline $\begin{array}{l}\text { C. testosteroni (Marcus and Talalay 1956) Tamaoka et al. } 1987 \\
(P . \text { testosteroni Marcus and Talalay } 1956)^{b}\end{array}$ & 5 & NCPPB $1969^{\mathrm{T}}$, NCPPB $1976, \mathrm{H} 24 \mathrm{D}, \mathrm{H} 29 \mathrm{C}$ \\
\hline $\begin{array}{l}\text { P. aeruginosa (Schroeter 1872) Migula } 1900(P . \text { polycolor } \\
\text { Clara 1930) }\end{array}$ & 14 & $\begin{array}{l}\text { NCPPB } 249, \text { NCPPB } 288, \text { NCPPB } 292, \text { NCPPB } 1224, \\
\text { NCPPB 1896, NCPPB } 1965^{\mathrm{T}} \text {, NCPPB 2195, NCPPB } \\
2650, \text { NCPPB } 2653, \text { IHRL Mia, JT2042a }\end{array}$ \\
\hline P. agarici Young 1970 & 16 & $\begin{array}{l}\text { NCPPB 1996, NCPPB 1999, NCPPB } 2289^{\mathrm{T}}, \text { NCPPB } \\
2290, \text { NCPPB } 2304, \text { NCPPB } 2471, \text { NCPPB } 2472\end{array}$ \\
\hline P. alcaligenes Monias $1928^{b}$ & 4 & NCPPB 1970 \\
\hline P. amygdali Psallidas and Panagopoulos 1975 & 5 & NCPPB $2607^{\mathrm{T}}$, NCPPB 2608, NCPPB 2610 \\
\hline $\begin{array}{l}\text { P. andropogonis (Smith 1911) Stapp } 1928 \text { (P. stizolobii (Wolf) } \\
\text { Stapp 1935, P. woodsii (Smith 1911) Stevens 1925) }\end{array}$ & 11 & $\begin{array}{l}\text { NCPPB } 450, \text { NCPPB } 934^{\mathrm{T}} \text {, NCPPB 968, NCPPB } 1024 \text {, } \\
\text { NCPPB 1130, NCPPB } 2157, \text { NCPPB } 2179 \text {, NCPPB } \\
2386, \text { NCPPB } 2868\end{array}$ \\
\hline P. asplenii (Ark and Tompkins 1946) Savulescu 1947 & 2 & NCPPB 959, NCPPB $1947^{\mathrm{T}}$ \\
\hline $\begin{array}{l}\text { P. aureofaciens Kluyver } 1956 \text { (P. fluorescens biotype E } \\
\text { Migula 1895) }\end{array}$ & 3 & NCPPB 1800, NCPPB 1801 \\
\hline $\begin{array}{l}\text { P. avenae Manns } 1909 \text { (P. alboprecipitans Rosen } 1922 \\
\text { P. setariae (Okabe 1934) Savulescu 1947) }\end{array}$ & 15 & $\begin{array}{l}\text { NCPPB } 1011^{\mathrm{T}}, \text { NCPPB } 1392, \text { NCPPB } 2398, \text { NCPPB } \\
2399, \text { NCPPB } 2400, \text { NCPPB 2401, NCPPB } 2402, \\
\text { NCPPB } 2403, \text { NCPPB 3354, NCPPB 3355, NCPPB } \\
3357\end{array}$ \\
\hline P. betle (Ragunathan 1928) Savulescu 1947 & 3 & NCPPB $323^{\mathrm{T}}$ \\
\hline P. caricapapayae Robbs 1956 & 4 & NCPPB 1872, NCPPB $1873^{\mathrm{T}}$, NCPPB 3439 \\
\hline P. caryophylli (Burkholder 1942) Starr and Burkholder 1942 & 5 & NCPPB 349, NCPPB 353, NCPPB 609, NCPPB $2151^{T}$ \\
\hline P. cattleyae (Pavarino 1911) Savulescu 1947 & 7 & NCPPB $961^{\mathrm{T}}$, NCPPB 1874 \\
\hline P. cepacia (ex Burkholder 1950) Palleroni and Holmes 1981 & 13 & $\begin{array}{l}\text { NCPPB } 945 \text {, NCPPB 946, NCPPB 1962, NCPPB } 2993^{\mathrm{T}} \text {, } \\
\text { NCPPB } 3025, \text { NCPPB } 3480, \text { A3228a, A3328b }\end{array}$ \\
\hline $\begin{array}{l}\text { P. chlororaphis (Guignard and Sauvageau 1894) Bergey et al. } \\
1930 \text { (P. fluorescens biotype D Migula 1895) }\end{array}$ & 8 & NCPPB 1598, NCPPB 1798, NCPPB 1799, NCPPB 2466 \\
\hline P. cichorii (Swingle 1925) Stapp 1928 & 14 & $\begin{array}{l}\text { NCPPB } 285, \text { NCPPB 906, NCPPB 907, NCPPB 908, } \\
\text { NCPPB 943T NCPPB 950, NCPPB 1022, NCPPB } \\
\text { 1511, NCPPB } 2379\end{array}$ \\
\hline P. cissicola (Takimoto 1939) Burkholder 1948 & 3 & NCPPB 2982, ICMP 8561 \\
\hline $\begin{array}{l}\text { P. corrugata (ex Scarlett et al. 1978) Roberts and Scarlett } \\
1981\end{array}$ & 12 & $\begin{array}{l}\text { NCPPB } 2445^{\mathrm{T}}, \text { NCPPB } 2447, \text { NCPPB } 2448, \text { NCPPB } \\
2455, \text { NCPPB } 2456, A 4227 \mathrm{a}, \mathrm{A} 4227 \mathrm{~b}, \mathrm{~A} 4379 / 98\end{array}$ \\
\hline P. ficuserectae Goto (1983) & 3 & ICMP 7848, ICMP 7849, ICMP 7850 \\
\hline P. flectens Johnson 1956 & 6 & NCPPB 538, ICMP 127, ICMP 745 \\
\hline $\begin{array}{l}\text { P. fluorescens Migula } 1895 \text { biovar } 1 \text { (P. fluorescens biotype A } \\
\text { Migula 1895) }\end{array}$ & 7 & NCPPB 1793, NCPPB $1964^{T}$ \\
\hline $\begin{array}{l}P . \text { fluorescens Migula } 1895 \text { biovar } 2(P . \text { fluorescens biotype B } \\
\text { Migula 1895) }\end{array}$ & 3 & NCPPB 1795 \\
\hline $\begin{array}{l}\text { P. fluorescens Migula } 1895 \text { biovar } 3 \text { (P. fluorescens biotype C } \\
\text { Migula } 1895)^{b}\end{array}$ & 3 & NCPPB 1796, NCPPB 1797 \\
\hline $\begin{array}{l}\text { P. fluorescens Migula } 1895 \text { biovar } 4 \text { (P. fluorescens biotype } \mathrm{F} \\
\text { Migula } 1895)^{b}\end{array}$ & 2 & NCPPB 1803 \\
\hline $\begin{array}{l}\text { P. fluorescens Migula } 1895 \text { biovar } 5 \text { (P. fluorescens biotype G } \\
\text { Migula } 1895)^{b}\end{array}$ & 2 & NCPPB 1805 \\
\hline P. fuscovaginae Miyajima et al. 1983 & 6 & $\begin{array}{l}\text { NCPPB } 3085^{\mathrm{T}} \text {, NCPPB 3598, NCPPB 3599, NCPPB } \\
\text { 3600, NCPPB 3601, NCPPB } 3602\end{array}$ \\
\hline "P. gingeri" Preece and Wong 1982 & 4 & NCPPB 3146, IHRL PgSA, IHRL PgSB \\
\hline $\begin{array}{l}\text { P. gladioli pv. gladioli Severini } 1913 \text { (P. marginata } \\
\text { (MuCulloch 1921) Stapp 1928) }\end{array}$ & 12 & $\begin{array}{l}\text { NCPPB } 644, \text { NCPPB 1051, NCPPB 1887, NCPPB } 1890, \\
\text { NCPPB } 1891^{\mathrm{T}} \text {, NCPPB } 3265, \text { NCPPB } 3266\end{array}$ \\
\hline $\begin{array}{l}\text { P. gladioli pv. alliicola (Burkholder 1942) Young et al. } 1978 \\
\text { (P. alliicola (Burkholder 1942) Stapp and Burkholder 1942) }\end{array}$ & 44 & $\begin{array}{l}\text { NCPPB } 947^{\mathrm{T}} \text {, NCPPB } 2478 \text {, NCPPB } 2940, \text { NCPPB } \\
\text { 2942, NCPPB 3307, NCPPB 3308, JT1159, JT1180D, } \\
\text { JT1228H, JT122C, JT1870A, JT1898C, JT1899B, } \\
\text { JT1900E, JT1900K, JT1960A, JT1963A, JT1970, } \\
\text { JT1972, JT1974, JT2140D, JT2142A, JT2161A }\end{array}$ \\
\hline P. glumae Kurita and Tabei 1967 & 7 & $\begin{array}{l}\text { NCPPB } 2391, \text { NCPPB } 2981^{\mathrm{T}}, \text { A4111, ICMP 3728, ICMP } \\
3729\end{array}$ \\
\hline P. hibiscicola Moniz 1963 & 2 & NCPPB $1683^{\mathrm{T}}$ \\
\hline P. marginalis pv. marginalis (Brown 1918) Stevens 1925 & 20 & $\begin{array}{l}\text { NCPPB } 667^{\mathrm{T}}, \text { NCPPB } 679, \text { NCPPB } 808, \text { NCPPB } 1187, \\
\text { NCPPB } 1307, \text { NCPPB 1557, NCPPB 1558, NCPPB } \\
1559 \text {, NCPPB 1603, NCPPB 1606, NCPPB 1676, } \\
\text { NCPPB 1677, NCPPB 1678, NCPPB 1690, NCPPB } \\
2380\end{array}$ \\
\hline
\end{tabular}


TABLE $1-$ Continued

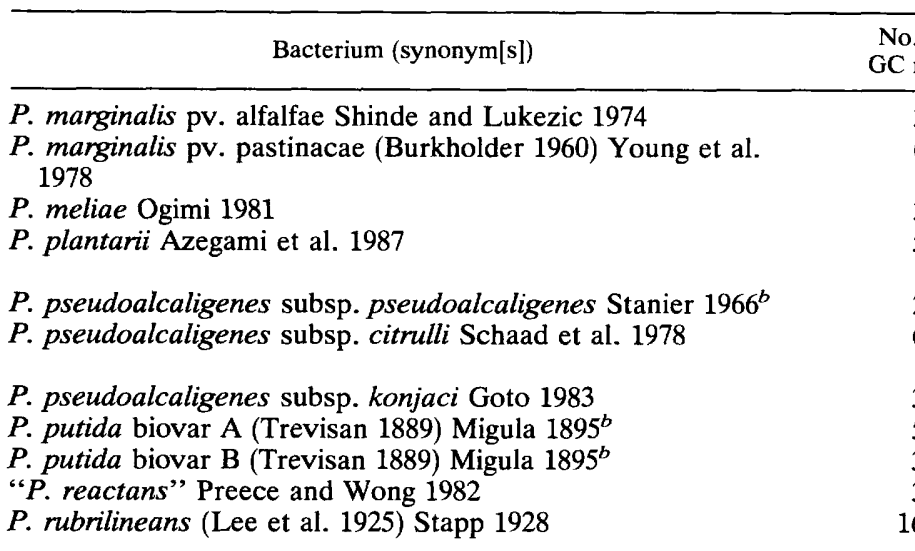

No. of

$\mathrm{GC}$ runs

3 NCPPB $2644^{\mathrm{T}}$, NCPPB 2645, NCPPB 2646

6 NCPPB 804, NCPPB 805, NCPPB $806^{\mathrm{T}}$, NCPPB 807, NCPPB 949, NCPPB 951

$3 \quad$ NCPPB $3033^{\mathrm{T}}$

5 NCPPB 3590, A4109, ICMP 9425, ICMP 9426, ICMP 9429

2 NCPPB 1959, NCPPB $1971^{\mathrm{T}}$

6 NCPPB 3055, NCPPB 3244, ICMP 6522, ICMP $7500^{\mathrm{T}}$, ICMP 7713

ICMP 7733 ${ }^{\mathrm{T}}$, ICMP 7734, ICMP 7851

NCPPB 244, NCPPB 1806, NCPPB 1807, IHRL 201

NCPPB 1809

NCPPB 2946, NCPPB 2947, IHRL 14

NCPPB 359, NCPPB 360, NCPPB 522, NCPPB $920^{\mathrm{T}}$, NCPPB 921, NCPPB 931, NCPPB 2890, NCPPB 2891, NCPPB 3029, NCPPB 3107, NCPPB 3108 , NCPPB 3111, NCPPB 3112, NCPPB 3113, NCPPB 3234

P. rubrisubalbicans (Christopher and Edgerton 1930) Krassilnikov 1949

P. solanacearum (Smith 1896) Smith 1914

6

NCPPB 932, NCPPB 1026, NCPPB $1027^{\mathrm{T}}$, NCPPB 1673, NCPPB 2994

$49 \quad$ NCPPB $325^{\mathrm{T}}$, NCPPB 339 , NCPPB 500, NCPPB 613 , NCPPB 616, NCPPB 643, NCPPB 789, NCPPB 790, NCPPB 909, NCPPB 1019, NCPPB 1225, NCPPB 1323, NCPPB 1331, NCPPB 1400, NCPPB 1483, NCPPB 1489, NCPPB 1579, NCPPB 1702, NCPPB 2088, NCPPB 2199, NCPPB 2201, NCPPB 2203, NCPPB 2314, NCPPB 2315, NCPPB 2797, NCPPB 2937, NCPPB 3190, NCPPB 3205, NCPPB 3362, N30, N40, N455, A3918, A3920, A3926, A3927, A3929, A3930, A3932, A4141, A4198, A4209

P. stutzeri (Lehmann and Neumann 1896) Sijderius $1946^{b}$ $2 \quad$ NCPPB 1972 , NCPPB $1973^{\mathrm{T}}$

$P$. syringae pv. syringae van Hall 1902

NCPPB 93, NCPPB $281^{\mathrm{T}}$, NCPPB 310 , NCPPB 524, NCPPB 1070, NCPPB 1071, NCPPB 1072, NCPPB 1073, NCPPB 1087, NCPPB 1088, NCPPB 1091, NCPPB 1282, NCPPB 2843, NCPPB 2844

$P$. syringae pv. phaseolicola (Burkholder 1926) Young et al.

1978 (P. phaseolicola (Burkholder 1926) Dowson 1943)

$P$. syringae pv. tomato (Okabe 1933) Young et al. 1978

(P. tomato (Okabe 1933) Alstaff 1944)

$P$. syzygii Roberts et al. 1990

P. tolaasii Pain 1919

\section{P. viridiflava Burkholder (1930) Dowson 1939}

S. paucimobilis (Holmes et al. 1977) Yabuuchi et al. 1991 $(P$. paucimobilis Holmes et al. 1977)

$X$. campestris pv. campestris (Pammel 1895) Dowson 1939

X. maltophilia (Hugh 1981) Swings et al. 1983 (P. maltophilia Hugh 1981)

Banana blood disease bacterium
NCPPB 52 ${ }^{T}$, NCPPB 380, NCPPB 604, NCPPB 1057, NCPPB 1098, NCPPB 1104, NCPPB 1321, NCPPB 1372, NCPPB 2571, NCPPB 3523, NCPPB 3524

NCPPB 1008 , NCPPB $1106^{\mathrm{T}}$, NCPPB 1107 , NCPPB 1367, NCPPB 1369

S107X, T326X, T328X, T329X, T394X

NCPPB 387, NCPPB 741, NCPPB 1116, NCPPB 1311 , NCPPB 1957, NCPPB $2192^{\mathrm{T}}$, NCPPB 2193, NCPPB 2194, NCPPB 2325, NCPPB 2412, NCPPB 2413, NCPPB 3148

NCPPB 389 , NCPPB $635^{\mathrm{T}}$, NCPPB 636 , NCPPB 1248 , NCPPB 1810, NCPPB 2012, NCPPB 2502

6 NCPPB 2439, A $4082 / 2$, A $4083 / 1$, A $4083 / 2$

6 NCPPB 403, NCPPB 528 ${ }^{\mathrm{T}}$, NCPPB 1043, NCPPB 1129 , NCPPB 1144, NCPPB 1645

10 NCPPB 1974, NCPPB 2923, IHRL MC55, H34bc, H7C, A4138

T334X, T379X, T389X, T391X, T394X

\footnotetext{
${ }^{a}$ All strains were obtained from the National Collection of Plant Pathogenic Bacteria, Harpenden, United Kingdom (NCPPB), except those with the following prefixes: A, diagnostic specimens from the Central Science Laboratory, Harpenden, United Kingdom; H, I. Harris, Royal Holloway and New College, London, United Kingdom; ICMP, International Collection of Microorganisms from Plants, Auckland, New Zealand; IHRL, Horticulture Research International, Littlehampton, United Kingdom; JT, J. Taylor, Horticulture Research International, Wellesbourne, United Kingdom; N, J. Neto, Instituto Biologico, Campinas, Brazil; S, T, and U, S. Eden-Green, Institute of Arable Crop Research, Rothamsted, Harpenden, Hertfordshire, United Kingdom.

${ }^{b}$ Nonpathogens.

${ }^{c}$ Opportunistic pathogens.
}

sucrose, $0.25 \mathrm{~g}$ of $\mathrm{MgSO}_{4} \cdot 7 \mathrm{H}_{2} \mathrm{O}, 0.5 \mathrm{~g}$ of $\mathrm{K}_{2} \mathrm{HPO}_{4}, 0.25 \mathrm{~g}$ of ferric ammonium citrate, $15 \mathrm{~g}$ of agar [Difco], 1 liter of distilled water) for 6 days at $28^{\circ} \mathrm{C}$. Banana blood disease bacterium strains were grown on Trypticase soy agar at $28^{\circ} \mathrm{C}$ for $48 \pm 2 \mathrm{~h}$.
Preparation of fatty acid profiles. Cells were harvested from confluent growth in the second and third quadrants of one or more steak plates by using a small sterile aluminum spatula. Portions (approximately $50 \mathrm{mg}$, fresh weight) of cells were transferred to Teflon-capped test tubes. Cellular 
TABLE 2. Fatty acids found in Pseudomonas spp.

\begin{tabular}{|c|c|c|c|}
\hline Shorthand name & $\begin{array}{l}\text { Equivalent chain } \\
\text { length }\end{array}$ & Systematic name & Trivial name \\
\hline \multicolumn{4}{|l|}{ Saturated acids } \\
\hline $10: 0$ & 10.000 & Decanoic acid & Capric acid \\
\hline $12: 0$ & 12.000 & Dódecanoic acid & Lauric acid \\
\hline $14: 0$ & 14.000 & Tetradecanoic acid & Myristic acid \\
\hline $15: 0$ & 15.000 & Pentadecanoic acid & \\
\hline $16: 0$ & 16.000 & Hexadecanoic acid & Palmitic acid \\
\hline $17: 0$ & 17.000 & Heptadecanoic acid & Margaric acid \\
\hline $18: 0$ & 18.000 & Octadecanoic acid & Stearic acid \\
\hline \multicolumn{4}{|l|}{ Unsaturated acids } \\
\hline $15: 1 \mathrm{~B}$ & 14.856 & Pentadecenoic acid isomer B & \\
\hline $16: 1 \mathrm{~B}$ & 15.774 & Hexadecenoic acid isomer $\mathrm{B}$ & \\
\hline $16: 1 \mathrm{C}$ & 15.908 & Hexadecenoic acid isomer $\mathrm{C}$ & \\
\hline $16: 1$ cis 9 & 15.817 & cis-9-Hexadecenoic acid & Palmitoleic acid \\
\hline $16: 1$ trans 9 & 15.856 & trans $-9-$ Hexadecenoic acid & Palmitelaidic acid \\
\hline $17: 1 \mathrm{~B}$ & 16.792 & Heptadecenoic acid isomer B & \\
\hline $17: 1 \mathrm{C}$ & 16.862 & Heptadecenoic acid isomer $\mathrm{C}$ & \\
\hline $18: 1$ cis 9 & 17.769 & cis-9-Octadecenoic acid & Oleic acid \\
\hline $18: 1$ cis 11 & 17.822 & cis-11-Octadecenoic acid & cis-Vaccenic acid \\
\hline $18: 1 \mathrm{~B}$ & 17.919 & Octadecenoic acid isomer B & \\
\hline \multicolumn{4}{|l|}{ Branched acids } \\
\hline $11: 0$ iso & 10.605 & 9-Methyl decanoic acid & \\
\hline $13: 0$ iso & 12.612 & 11-Methyl dodecanoic acid & \\
\hline $14: 0$ iso & 13.618 & 12-Methyl tridecanoic acid & Isomyristic acid \\
\hline $15: 1$ iso $F$ & 14.414 & 13-Methyl tetradecenoic acid isomer F & \\
\hline $15: 0$ iso & 14.621 & 13-Methyl tetradecanoic acid & \\
\hline $15: 0$ anteiso & 14.711 & 12-Methyl tetradecanoic acid & \\
\hline $16: 0$ iso & 15.626 & 14-Methyl pentadecanoic acid & Isopalmitic acid \\
\hline $17: 1$ iso $F$ & 16.416 & 15-Methyl hexadecenoic acid isomer $F$ & \\
\hline $17: 0$ iso & 16.629 & 15-Methyl hexadecanoic acid & Isomargaric acid \\
\hline 17:0 anteiso & 16.722 & 14-Methyl hexadecanoic acid & Anteisomargaric acid \\
\hline \multicolumn{4}{|l|}{ Cyclopropane acids } \\
\hline 17:0 cyclo & 16.888 & cis-9,10-Methylene hexadecanoic acid & \\
\hline 19:0 cyclo $9-10$ & 18.860 & cis-9,10-Methylene octadecanoic acid & Dihydrosterulic acid \\
\hline 19:0 cyclo $11-12$ & 18.900 & cis-11,12-Methylene octadecanoic acid & Lactobacillic acid \\
\hline \multicolumn{4}{|l|}{ Hydroxy acids } \\
\hline 10:0 3-OH & 11.423 & 3-Hydroxydecanoic acid & 3-Hydroxycapric acid \\
\hline $11: 0$ iso $3-\mathrm{OH}$ & 12.090 & 3-Hydroxy-9-methyl decanoic acid & \\
\hline $12: 02-\mathrm{OH}$ & 13.178 & 2-Hydroxydodecanoic acid & 2-Hydroxylauric acid \\
\hline $12: 13-\mathrm{OH}$ & 13.289 & 3-Hydroxydodecenoic acid & \\
\hline $12: 03-\mathrm{OH}$ & 13.455 & 3-Hydroxydodecanoic acid & 3-Hydroxylauric acid \\
\hline $13: 0$ iso $3-\mathrm{OH}$ & 14.110 & 3-Hydroxy-11-methyl dodecanoic acid & \\
\hline $13: 02-\mathrm{OH}$ & 14.191 & 2-Hydroxytridecanoic acid & \\
\hline $14: 02-\mathrm{OH}$ & 15.205 & 2-Hydroxytetradecanoic acid & 2-Hydroxymyristic acid \\
\hline 14:0 3-OH & 15.490 & 3-Hydroxytetradecanoic acid & 3-Hydroxymyristic acid \\
\hline $15: 02-\mathrm{OH}$ & 16.217 & 2-Hydroxypentadecanoic acid & \\
\hline $16: 12-\mathrm{OH}$ & 17.047 & 2-Hydroxyhexadecenoic acid & \\
\hline $16: 02-\mathrm{OH}$ & 17.235 & 2-Hydroxyhexadecanoic acid & 2-Hydroxypalmitic acid \\
\hline $16: 03-\mathrm{OH}$ & 15.520 & 3-Hydroxyhexadecanoic acid & 2-Hydroxypalmitic acid \\
\hline $18: 12-\mathrm{OH}$ & 19.088 & 2-Hydroxyoctadecenoic acid & \\
\hline \multicolumn{4}{|c|}{ Unknown fatty acids } \\
\hline UNK 9.521 & 9.521 & & \\
\hline UNK 11.798 & 11.798 & & \\
\hline UNK 13.961 & 13.961 & & \\
\hline UNK 14.503 & 14.503 & & \\
\hline UNK 19.368 & 19.368 & & \\
\hline
\end{tabular}

lipids were saponified, and the fatty acids were methylated. Fatty acid methyl esters (FAMEs) were extracted and purified. The methods which I used have been described elsewhere (26-28). Profiles were obtained after gas chromatography (GC) (Hewlett-Packard model 5890 gas chromatograph) through a 25-m Hewlett-Packard fused silica capillary column lined with methyl phenyl silicone by using split injection $(1 \mu \mathrm{l})$ and hydrogen as the carrier gas $(55 \mathrm{ml} / \mathrm{min})$. The injector temperature was $250^{\circ} \mathrm{C}$. The column tempera- ture was increased from 170 to $270^{\circ} \mathrm{C}$ at a rate of $5^{\circ} \mathrm{C} / \mathrm{min}$. Detection was by flame ionization. Peaks were integrated by using a Hewlett-Packard model 3392A integrator. Individual FAMEs were quantified and identified by using the peaknaming table component of the Microbial Identification System software package (Microbial ID, Inc., Newark, Del.). Quantities were expressed as percentages of the total named FAME peak area. Identification of FAMEs was based on calculation of equivalent chain lengths. 
TABLE 3. Fatty acid profiles for $P$. syringae and its close relatives (subgroup 1a)

\begin{tabular}{|c|c|c|c|c|c|c|c|c|}
\hline \multirow[b]{2}{*}{ Fatty acid } & \multicolumn{8}{|c|}{$\%$ in profile $(\mathrm{SD})$} \\
\hline & $\begin{array}{l}P \text { syringae pv. } \\
\text { syringae }\end{array}$ & $\begin{array}{c}P . \text { syringae } \\
\text { tomato }\end{array}$ & $\begin{array}{l}\text { P. syringae pv. } \\
\text { phaseolicola }\end{array}$ & P. caricapapayae & P. cichorii & $P$. ficuserectae & P. meliae & P. viridiflava \\
\hline $10: 0$ & $\operatorname{tr}^{a}$ & tr & $\operatorname{tr}$ & $\operatorname{tr}$ & $0.1(0.1)$ & & $\operatorname{tr}$ & $\operatorname{tr}$ \\
\hline 10:0 3-OH & $2.4(0.3)$ & $3.0(0.4)$ & $3.6(1.4)$ & $2.6(0.3)$ & $2.6(0.3)$ & $2.1(1.8)$ & $3.0(0.2)$ & $2.3(0.3)$ \\
\hline $12: 0$ & $4.8(0.3)$ & $4.7(0.3)$ & $4.2(1.4)$ & $4.6(0.3)$ & $4.8(0.2)$ & $4.3(0.2)$ & $4.7(0.4)$ & $5.1(0.2)$ \\
\hline $\begin{array}{l}12: 02-\mathrm{OH} \\
12: 13-\mathrm{OH}\end{array}$ & $2.9(0.2)$ & $2.6(0.1)$ & $2.5(0.8)$ & $2.7(0.1)$ & $\begin{array}{l}2.6(0.2) \\
0.2(0.4)\end{array}$ & $3.0(0.2)$ & $2.9(0.3)$ & $2.4(0.2)$ \\
\hline $12: 03-\mathrm{OH}$ & $4.1(0.3)$ & $4.0(0.2)$ & $3.6(1.2)$ & $3.0(1.1)$ & $4.1(0.3)$ & $3.7(0.3)$ & $4.1(0.7)$ & $4.0(0.1)$ \\
\hline $14: 0$ & $0.2(0.1)$ & $0.2(0.1)$ & $0.6(1.1)$ & $0.2(0.1)$ & $0.2(0.1)$ & $0.1(0.1)$ & $0.3(0.1)$ & tr \\
\hline $15: 0$ & $\operatorname{tr}$ & & $\operatorname{tr}$ & & & & & \\
\hline $14: 03-\mathrm{OH}$ & & & $0.7(2.2)$ & & & & & \\
\hline $16: 1$ cis 9 & $38.6(1.6)$ & $40.5(1.8)$ & $34.9(2.1)$ & $35.6(2.4)$ & $36.0(2.1)$ & $36.4(0.1)$ & $34.3(1.1)$ & $37.2(0.8)$ \\
\hline $16: 0$ & $26.4(0.15)$ & $26.0(1.4)$ & $26.0(1.8)$ & $24.8(1.5)$ & $26.1(1.6)$ & $24.4(1.2)$ & $30.8(0.1)$ & $26.1(1.3)$ \\
\hline $16: 03-\mathrm{OH}$ & & & $0.7(0.7)$ & tr & & & $0.4(0.1)$ & \\
\hline $17: 0$ iso & $0.2(0.2)$ & $\operatorname{tr}$ & $0.3(0.2)$ & $0.2(0.1)$ & & & & $0.2(0.2)$ \\
\hline 17:0 cyclo & $0.3(0.6)$ & & $2.0(1.8)$ & $1.8(1.9)$ & $\operatorname{tr}$ & $1.3(0.2)$ & $0.7(0.1)$ & $0.4(0.3)$ \\
\hline $17: 0$ & tr & & $\operatorname{tr}$ & $0.2(0.1)$ & & & & \\
\hline $18: 1$ cis 11 & $18.4(1.5)$ & $17.8(1.1)$ & $19.0(2.1)$ & $22.9(1.8)$ & $21.5(1.4)$ & $23.6(0.4)$ & $17.7(1.0)$ & $20.8(1.6)$ \\
\hline $18: 0$ & $1.2(0.8)$ & $0.9(0.2)$ & $0.4(0.1)$ & $1.0(0.1)$ & $1.2(0.2)$ & $1.1(0.1)$ & $0.9(0.1)$ & $1.3(0.1)$ \\
\hline 19:0 cyclo $9-10$ & $0.2(0.2)$ & & $0.2(0.2)$ & $0.2(0.2)$ & $0.2(0.1)$ & & $\operatorname{tr}$ & $\operatorname{tr}$ \\
\hline 19:0 cyclo $11-12$ & & $\operatorname{tr}$ & $\operatorname{tr}$ & & & & & \\
\hline
\end{tabular}

${ }^{a}$ tr, trace amounts are present in some strains.

For each taxon, duplicate fatty acid profiles of at least one strain were prepared. All profiles for each taxon were pooled, and the mean and standard deviation for each FAME were determined. Groupings were based on differences in the types and amounts of FAMEs present. FAMEs are referred to below as the parent fatty acids.

\section{RESULTS}

For each taxon, the mean percentages for all of the major FAMEs (mean percentage, $>0.2 \%$ ) were used for further analysis. Minor FAMEs, which were present at lower values or which were found only in occasional strains of a taxon, were omitted. The reproducibility of profiles was good. Standard deviations were generally lower for taxa when multiple runs of a single strain were examined than when single runs of several strains were examined. Most strains of a given taxon had profiles which were qualitatively and quantitatively similar. Variation between strains was greatest for the cyclopropane acids. The percentages of these acids tended to increase with the age of the culture (26).

In many cases fatty acids which accounted for less than $1 \%$ of the total named peak area were consistently found in all strains of a particular taxon, further illustrating the reproducibility and specificity of the profiles. However, fatty acids present at levels less than $0.2 \%$ were often not detected in some repeat runs or in runs of other strains, usually as a result of reduced total peak area caused by use of a lower fresh weight of cells.

For all gas chromatographic runs included in this analysis, more than $85 \%$ of the total peak area consisted of peaks that were named. For most runs the value was 98 to $100 \%$. A total of 45 fatty acids were identified and used in this analysis; an additional 5 fatty acids were present in substantial quantities $(>0.2 \%)$ in some strains. An equivalent chain length was calculated for each unidentified fatty acid, and the resulting values were used as interim names (for example, the unknown with an equivalent chain length of 14.503 was designated UNK 14.503). Mass spectra of some of these fatty acids were prepared, and the results are discussed below.

The 50 fatty acids which I identified or characterized are classified and listed along with their systematic and trivial names (where known) in Table 2. Shorthand chemical symbols (e.g., 10:0 3-OH) are used below.

All of the strains contained 16:0, 16:1 cis 9 , and 18:1 cis 11, and the FAMEs of these acids were often the most abundant FAMEs. Most strains also contained 14:0. Six discrete groups of strains were identified on the basis of the types of hydroxy acids found (referred to as the core hydroxy fatty acids), although these fatty acids usually accounted for less than $10 \%$ of the total peak area in a profile. These hydroxy fatty acids were of three types, 2-hydroxy, 3-hydroxy, and iso-branched 3-hydroxy. Several of the groups were further subdivided on the basis of additional hydroxy acids (referred to as minor hydroxy fatty acids). Each subgroup contained one or more taxa. A few taxa contained strains that belonged to more than one group or subgroup. The profiles for groups 1 through 6 are shown in Tables 3 through 8 . Most taxa exhibited great uniformity in the profiles of their strains. The few taxa which exhibited great variation are described below. Most taxa at and above subspecific rank could be differentiated on the basis of quantitative differences in one or more fatty acids. There were few qualitative differences among the profiles of taxa included in the same subgroup.

Group 1. All members of group 1 contained the hydroxy acids 10:0 3-OH and 12:0 3-OH, as well as 12:0, 16:1 cis 9, 16:0, and 18:1 cis 11 . Most also contained 14:0, 17:0 cyclo, and 18:0. The compositions of subgroups were determined on the basis of the presence of other hydroxy acids and in some cases on the basis of the relative amounts of these other hydroxy acids. Six subgroups were differentiated. Strains belonging to subgroup $1 \mathrm{a}, 1 \mathrm{~b}, 1 \mathrm{c}, 1 \mathrm{e}$, and if profiles all contained 10:0 3-OH, 12:0 2-OH, and 12:0 3-OH. Differentiation was based primarily on the relative amounts of 10:0 3-OH. Subgroup 1a contained 27 taxa, whereas subgroups lb, 1c, le, and if each contained a single taxon. Subgroup 1b profiles also contained 14:0 3-OH and 16:0 3-OH, whereas 
TABLE 4. Fatty acid profiles for $P$. fluorescens and its close relatives (subgroup 1a)

\begin{tabular}{|c|c|c|c|c|c|c|c|c|c|}
\hline \multirow[b]{2}{*}{ Fatty acid } & \multicolumn{9}{|c|}{$\%$ in profile $(\mathrm{SD})$} \\
\hline & $\begin{array}{l}P . \text { fluo- } \\
\text { rescens } \\
\text { biovar } 1\end{array}$ & $\begin{array}{l}P . \text { fluo- } \\
\text { rescens } \\
\text { biovar } 2\end{array}$ & $\begin{array}{l}P . \text { fluo- } \\
\text { rescens } \\
\text { biovar } 3\end{array}$ & $\begin{array}{l}P . \text { fluo- } \\
\text { rescens } \\
\text { biovar } 4\end{array}$ & $\begin{array}{l}P . \text { fluo- } \\
\text { rescens } \\
\text { biovar } 5\end{array}$ & $\begin{array}{l}P . \text { aerugi- } \\
\text { nosa }\end{array}$ & P. agarici & $\begin{array}{c}P . \text { asple- } \\
\text { nii }\end{array}$ & $\begin{array}{c}P . \text { aureo- } \\
\text { faciens }\end{array}$ \\
\hline $10: 0$ & $\operatorname{tr}^{a}$ & $\operatorname{tr}$ & tr & $0.5(0.2)$ & tr & tr & & & $0.2(0.1)$ \\
\hline $10.03-\mathrm{OH}$ & $3.1(0.2)$ & $3.0(0.4)$ & $3.6(0.6)$ & $5.2(1.0)$ & $3.7(0.6)$ & $2.9(0.6)$ & $3.0(0.5)$ & $3.1(0.1)$ & $4.7(0.5)$ \\
\hline $12: 0$ & $2.4(0.3)$ & $2.9(0.4)$ & $1.8(0.6)$ & $6.6(0.2)$ & $2.7(0.1)$ & $3.1(0.4)$ & $2.0(0.5)$ & $1.1(0.1)$ & $1.6(0.2$ \\
\hline $12: 02-\mathrm{OH}$ & $4.7(0.4)$ & $3.8(0.4)$ & $5.1(0.4)$ & $2.2(0.2)$ & $4.7(0.3)$ & $4.1(0.4)$ & $5.1(0.5)$ & $5.5(0.1)$ & $5.6(0.2$ \\
\hline $12: 13-\mathrm{OH}$ & & & & $1.9(0.8)$ & & tr & & & $0.6(0.2$ \\
\hline $12: 03-\mathrm{OH}$ & $4.2(0.3)$ & $3.9(0.1)$ & $4.0(0.2)$ & $4.2(0.7)$ & $4.2(0.1)$ & $4.1(0.3)$ & $4.3(0.4)$ & $4.3(0.3)$ & $4.9(0.1)$ \\
\hline $14: 0$ & $0.4(0.1)$ & $0.4(0.1)$ & $0.4(0)$ & $0.3(0)$ & $0.3(0)$ & $0.8(0.2)$ & $0.9(0.3)$ & $0.3(0.1)$ & $0.5(0.1$ \\
\hline $15: 0$ & $0.4(0.4)$ & $0.1(0.1)$ & $0.3(0)$ & $0.2(0)$ & $0.2(0)$ & $0.4(0)$ & $0.4(0.2)$ & $\operatorname{tr}$ & $0.3(0.1$ \\
\hline $14: 03-\mathrm{OH}$ & & & & $0.2(0.1)$ & & & & & $0.4(0.1$ \\
\hline 16:1 trans 9 & & & & & & $1.3(2.0)$ & $\operatorname{tr}$ & & \\
\hline $16: 1$ cis 9 & $28.8(1.4)$ & $27.5(2.7)$ & $33.7(2.0)$ & $29.3(0.9)$ & $29.1(2.0)$ & $14.2(2.1)$ & $27.7(4.2)$ & $34.9(0.4)$ & $22.9(6.1$ \\
\hline $16: 0$ & $29.8(1.3)$ & $32.1(2.1)$ & $33.1(2.2)$ & $26.4(0.1)$ & $30.3(1.2)$ & $25.0(1.6)$ & $36.1(2.8)$ & $29.8(2.8)$ & $29.5(2.2$ \\
\hline $17: 0$ iso & $0.1(0.1)$ & & $0.2(0)$ & $0.2(0.1)$ & $0.2(0)$ & & & $0.2(0.1)$ & $\operatorname{tr}$ \\
\hline 17:0 cyclo & $7.5(1.3)$ & $7.6(1.8)$ & $5.2(0.8)$ & $6.4(0.9)$ & $6.6(0.6)$ & $0.8(0.7)$ & $9.8(3.4)$ & $2.6(1.5)$ & $13.6(5.5$ \\
\hline $17: 0$ & $0.4(0.5)$ & $0.1(0.1)$ & $0.4(0.1)$ & $0.2(0)$ & $0.2(0)$ & $\operatorname{tr}$ & $0.2(0.2)$ & $0.2(0.1)$ & $0.2(0.1$ \\
\hline $18: 1$ cis 11 & $16.7(1.4)$ & $16.6(1.0)$ & $11.0(1.3)$ & $14.6(2.0)$ & $16.6(0.7)$ & $40.6(2.2)$ & $9.0(2.6)$ & $17.0(3.8)$ & 13.3 \\
\hline $18: 0$ & $0.8(0.2)$ & $1.1(0.2)$ & $0.9(0.4)$ & $0.4(0.1)$ & $0.6(0.2)$ & $0.6(0.1)$ & $0.8(0.3)$ & $0.9(0.1)$ & $0.4(0.1$ \\
\hline 19:0 cyclo $11-12$ & $0.3(0.2)$ & $0.8(0.2)$ & $0.1(0.1)$ & $0.3(0.1)$ & $0.4(0.1)$ & $1.2(1.2)$ & & & $0.7(0.4$ \\
\hline
\end{tabular}

${ }^{a}$ tr, trace amounts are present in some strains.

subgroup 1c profiles contained the 2-hydroxy analogs 14:0 2-OH and 16:0 2-OH. Subgroup 1d profiles contained only the two root hydroxy acids for group 1, 10:0 3-OH and 12:0 3-OH. The profiles of occasional strains or occasional runs of a particular strain contained trace amounts of other hydroxy acids. Subgroup le and 1f were differentiated from subgroup la by quantitative differences in the core hydroxy acids.

The nonhydroxy acids were often important in differentiating among taxa at specific and infraspecific levels, but they did not have the same apparent value in classifying strains at the generic level. Qualitative and quantitative differences in many of these acids were found.

(i) Subgroup 1a. Subgroup la contained $P$. agarici, $P$. aeruginosa, $P$. asplenii, $P$. aureofaciens, $P$. caricapapayae, $P$. chlororaphis, $P$. cichorii, $P$. ficuserectae, $P$. fluorescens biovar 1, $P$. fluorescens biovar 2, $P$. fluorescens biovar $3, P$. fluorescens biovar 4, $P$. fluorescens biovar 5, $P$. fuscovaginae, " $P$. gingeri," $P$. marginalis pv. alfalfae, $P$. marginalis pv. marginalis, $P$. marginalis pv. pastinacae, $P$. meliae, $P$. putida biovar A, $P$. putida biovar B, " $P$. reactans," $P$. syringae pv. phaseolicola, $P$. syringae pv. syringae, $P$. syringae pv. tomato, $P$. tolaasii, and $P$. viridiflava. All of the fluorescent pseudomonads tested fell into this subgroup. Subgroup 1a is perhaps most closely related to subgroups 1e and 1f, whose profiles contained the same three hydroxy acids (10:0 3-OH, 12:0 2-OH, and 12:0 3-OH). Subgroup 1a was differentiated on the basis of having less than 5 to $6 \%$ 10:0 3-OH (Tables 3 and 4). The members of subgroups 1e and $1 \mathrm{f}$ contained significantly more of this acid.

(ii) Subgroup 1b. Subgroup $1 \mathrm{~b}$ contained $P$. corrugata. This species was differentiated on the basis of having significant amounts of 12:1 3-OH, 14:0 3-OH, and 16:0 3-OH in addition to the three core hydroxy acids $(10: 03-\mathrm{OH}, 12: 0$ 2-OH, and 12:0 3-OH) (Table 5). All of the strains also contained two other acids which were not named (equivalent chain lengths of 13.961 and 14.503); each of these acids was present at a level of 0.5 to $2.0 \%$. No other group 1 strain contained significant amounts of these acids. Mass spectra of the compounds with equivalent chain lengths of 13.961 and
14.503 indicated that they were branched hydroxy acids containing 13 and 14 carbon atoms, respectively; for both, the hydroxy groups were not in the 2 or 3 position.

(iii) Subgroup 1c. Subgroup 1c contained $P$. rubrisubalbicans. This species was differentiated on the basis of having significant amounts of 14:0 2-OH and smaller amounts of 16:0 2-OH (Table 5). All of the other acids were qualitatively typical of subgroup $1 \mathrm{a}$, although the quantities of 10:0 3-OH and 12:0 2-OH were significantly lower than the quantities in subgroup la strains.

(iv) Subgroup 1d. Subgroup 1d contained $P$. alcaligenes, $P$. pseudoalcaligenes subsp. pseudoalcaligenes, and $P$. stutzeri. Subgroup 1d was characterized by the relative lack of 12:0 2-OH (Table 5), which was found only in trace amounts in some strains. This subgroup differed significantly from the other subgroups not only in the hydroxy acids but also in some of the other acids (notably, the presence in some strains of 16:1 trans 9 and the presence of significantly higher amounts of 12:0 and 18:1 cis 11 and significantly lower amounts of 16:0).

(v) Subgroup 1e. Subgroup 1e contained $P$. amygdali. The subgroup le profile was qualitatively similar to that of subgroup 1a in that except for a trace of 14:0 3-OH the only hydroxy acids were the core acids 10:0 3-OH, 12:0 2-OH, and 12:0 3-OH. The major difference was that the relative amounts of the hydroxy acids were much greater (26 to $32 \%$, compared with less than $15 \%$ for subgroup 1a members). 10:0 3-OH was by far the most abundant acid in the whole profile $(>20 \%)$. P. amygdali was the only bacterium in which a hydroxy acid was more abundant than $16: 1$ cis $9,16: 0$, or 18:1 cis 11 . Very few minor acids were present in the profile. $P$. amygdali was the only bacterium other than $P$. syringae and its close relatives (Table 3 ) that contained 19:0 cyclo 9-10. It was also unusual that it also contained 19:0 cyclo 11-12. Another unusual feature was the presence of an unknown fatty acid (UNK 19.368) in significant quantities $(4.7 \%)$. This fatty acid occurred in trace amounts in some $P$. gladioli pv. alliicola strains (group 2) (data not shown).

(vi) Subgroup 1f. Subgroup if contained $P$. cattleyae NCPPB 1874. This strain formed a separate subgroup in 
TABLE 4 Continued

\begin{tabular}{|c|c|c|c|c|c|c|c|c|c|}
\hline \multicolumn{10}{|c|}{$\%$ in profile $(\mathrm{SD})$} \\
\hline $\begin{array}{l}\text { P. chloro- } \\
\text { raphis }\end{array}$ & $\begin{array}{l}P . \text { fusco- } \\
\text { vaginae }\end{array}$ & $\begin{array}{l}\text { "P. gin- } \\
\text { geri" }\end{array}$ & $\begin{array}{c}P . \text { marginalis } \\
\text { pv. margin- } \\
\text { alis }\end{array}$ & $\begin{array}{l}P . \text { margin- } \\
\text { alis pv. } \\
\text { alfalfae }\end{array}$ & $\begin{array}{l}P . \text { marginalis } \\
\text { pv. pasti- } \\
\text { naceae }\end{array}$ & $\begin{array}{l}P . \text { putida } \\
\text { biovar A }\end{array}$ & $\begin{array}{c}\text { P. putida } \\
\text { biovar B }\end{array}$ & $\begin{array}{l}\text { "P. reac- } \\
\text { tans" }\end{array}$ & P. tolaasii \\
\hline & & $\mathrm{tr}$ & $\operatorname{tr}$ & $\operatorname{tr}$ & $\operatorname{tr}$ & $0.4(0.4)$ & & & $\operatorname{tr}$ \\
\hline $4.0(0.2)$ & $4.1(0.4)$ & $3.3(0.7)$ & $3.5(0.4)$ & $3.8(0.3)$ & $3.0(0.3)$ & $5.3(1.1)$ & $3.3(0.6)$ & $3.4(1.1)$ & $3.2(0.6)$ \\
\hline $1.9(0.8)$ & $1.4(0.4)$ & $1.7(0.8)$ & $2.9(0.5)$ & $2.7(0.8)$ & $2.5(0.1)$ & $2.1(0.5)$ & $1.8(0.7)$ & $3.2(1.0)$ & $2.0(0.5)$ \\
\hline $5.1(0.6)$ & $5.8(0.2)$ & $5.7(1.6)$ & $4.2(0.3)$ & $4.7(0.4)$ & $4.5(0.2)$ & $5.1(1.1)$ & $3.6(3.1)$ & $4.8(1.2)$ & $5.0(0.4)$ \\
\hline tr & & & & & & $0.7(0.3)$ & & & \\
\hline $4.4(0.3)$ & $4.6(0.5)$ & $4.4(0.6)$ & $3.9(0.5)$ & $4.3(0.1)$ & $3.9(0.3)$ & $4.8(0.5)$ & $2.7(2.3)$ & $5.1(1.3)$ & $4.2(0.4)$ \\
\hline $0.5(0.1)$ & $0.3(0.2)$ & $0.4(0.2)$ & $0.4(0.3)$ & $0.8(0.5)$ & $0.3(0)$ & $0.7(0.4)$ & $0.6(0.2)$ & $0.2(0.2)$ & $0.3(0.1)$ \\
\hline tr & $0.1(0.1)$ & tr & $0.3(0.2)$ & $0.2(0.2)$ & $0.2(0)$ & $0.2(0.2)$ & $0.4(0.1)$ & tr & $0.2(0.1)$ \\
\hline & & & & & & $2.2(3.0)$ & & & \\
\hline $32.1(3.2)$ & $36.2(2.5)$ & $25.8(1.6)$ & $31.1(3.0)$ & $35.3(2.4)$ & $31.2(2.3)$ & $24.1(3.7)$ & $26.2(7.7)$ & $29.4(3.3)$ & $28.8(5.0)$ \\
\hline $31.2(2.7)$ & $27.9(1.5)$ & 31.1 (1.6) & $30.7(1.8)$ & $32.9(3.7)$ & $31.1(0.5)$ & $28.9(2.0)$ & $31.5(2.4)$ & $30.0(0.2)$ & $29.4(3.3)$ \\
\hline & $\operatorname{tr}$ & $\operatorname{tr}$ & $\operatorname{tr}$ & tr & $\operatorname{tr}$ & & & tr & tr \\
\hline $4.9(2.6)$ & $1.9(1.9)$ & $10.1(4.8)$ & $6.2(2.3)$ & $4.6(2.0)$ & $6.7(2.7)$ & $5.9(2.3)$ & $13.9(2.9)$ & $7.5(4.7)$ & $8.1(4.4)$ \\
\hline tr & $0.2(0.1)$ & $0.2(0.1)$ & $0.2(0.1)$ & $0.1(0.1)$ & $0.2(0)$ & $\operatorname{tr}$ & $0.2(0.1)$ & $\operatorname{tr}$ & $0.3(0.2)$ \\
\hline $14.1(2.2)$ & $16.2(2.4)$ & $12.8(4.4)$ & $15.4(2.3)$ & $10.0(5.3)$ & $15.2(1.2)$ & $18.5(1.1)$ & $15.4(1.9)$ & $15.1(0.3)$ & $16.7(2.8)$ \\
\hline $0.6(0.4)$ & $0.7(0.1)$ & $0.7(0.1)$ & $0.7(0.2)$ & $0.5(0.4)$ & $0.7(0.1)$ & $0.8(0.3)$ & $0.4(0.2)$ & $0.9(0.2)$ & $0.8(0.3)$ \\
\hline tr & & $0.5(0.5)$ & $0.2(0.2)$ & $\operatorname{tr}$ & $0.3(0.2)$ & $\operatorname{tr}$ & & $0.6(0.6)$ & $0.5(0.4)$ \\
\hline
\end{tabular}

group 1, intermediate between subgroups $1 \mathrm{a}$ and $1 \mathrm{e}$ in that the major hydroxy acid was 10:0 3-OH (ca. 10\%) (Table 5). The profile also contained significant amounts of $12: 13-\mathrm{OH}$, as well as a wide range of minor acids.

Group 2. Group 2 was readily differentiated from the other groups on the basis of hydroxy fatty acid composition. The core hydroxy fatty acids of group 1, 10:0 3-OH, 12:0 2-OH, and 12:0 3-OH, were not represented apart from an occasional trace of 10:0 3-OH (Table 6) except in two strains of $P$. glumae. In many profiles the smallest acid was 14:0. For this

TABLE 5. Fatty acid profiles for Pseudomonas subgroups $1 \mathrm{~b}$ through if

\begin{tabular}{|c|c|c|c|c|c|c|c|}
\hline \multirow{3}{*}{ Fatty acid } & \multirow{3}{*}{$\begin{array}{c}\text { Fatty acid } \\
\text { subgroup } 1 \text { : } \\
P . \text { corrugata }\end{array}$} & \multirow{3}{*}{$\begin{array}{l}\text { Fatty acid } \\
\text { subgroup } 1 \mathrm{c} \text { : } \\
P \text {. rubrisub- } \\
\text { albicans }\end{array}$} & \multicolumn{3}{|c|}{$\%$ in profile (SD) } & \multirow{3}{*}{$\begin{array}{l}\text { Fatty acid } \\
\text { subgroup 1e: } \\
P . \text { amygdali }\end{array}$} & \multirow{3}{*}{$\begin{array}{c}\text { Fatty acid } \\
\text { subgroup } 1 \mathrm{f}: \\
P \text {. cattleyae } \\
\text { NCPPB } 1874\end{array}$} \\
\hline & & & \multicolumn{3}{|c|}{ Fatty acid subgroup 1d } & & \\
\hline & & & $P$. alcaligenes & $\begin{array}{l}\text { P. pseudoalcaligenes } \\
\text { subsp. pseudo- } \\
\text { alcaligenes }\end{array}$ & P. stutzeri & & \\
\hline $10: 0$ & $0.5(0.4)$ & $0.3(0.1)$ & $2.3(0.1)$ & $\operatorname{tr}^{a}$ & $0.2(0.1)$ & $\operatorname{tr}$ & $1.2(1.6)$ \\
\hline $10: 03-\mathrm{OH}$ & $4.6(0.6)$ & $3.3(0.1)$ & $3.7(0.2)$ & $3.0(0.2)$ & $2.9(0.1)$ & $14.3(4.5)$ & $10.1(0.9)$ \\
\hline $12: 0$ & $3.6(0.3)$ & $3.6(0.1)$ & $5.2(0.1)$ & $7.9(0.3)$ & $8.3(0.3)$ & $5.1(0.4)$ & $1.3(0.1)$ \\
\hline $12: 02-\mathrm{OH}$ & $3.8(0.2)$ & $0.4(0.1)$ & $\operatorname{tr}$ & & $\operatorname{tr}$ & $2.0(0.6)$ & $4.9(0.4)$ \\
\hline $12: 13-\mathrm{OH}$ & $1.1(0.5)$ & & & & & $\operatorname{tr}$ & $1.3(0.1)$ \\
\hline $12: 03-\mathrm{OH}$ & $4.4(0.4)$ & $2.9(0.3)$ & $3.2(0.3)$ & $3.8(0.4)$ & $2.6(0.3)$ & $4.4(1.0)$ & $4.0(0.3)$ \\
\hline UNK 13.961 & $0.8(0.4)$ & & & & & & \\
\hline $14: 0$ & $\operatorname{tr}$ & $0.5(0.1)$ & $3.6(0.1)$ & $0.3(0)$ & $0.8(0.4)$ & $0.2(0.1)$ & $0.4(0)$ \\
\hline UNK 14.503 & $0.5(0.3)$ & & & & & & \\
\hline $15: 0$ & tr & & $2.0(0.2)$ & $0.7(0.2)$ & & & $0.2(0)$ \\
\hline $14: 02-\mathrm{OH}$ & & $2.1(0.6)$ & & & & & \\
\hline $14: 03-\mathrm{OH}$ & $1.0(0.3)$ & & & & & $0.2(0.1)$ & $\operatorname{tr}$ \\
\hline $16: 1$ cis 9 & $29.1(3.7)$ & $36.5(2.2)$ & $19.8(1.4)$ & $19.0(2.9)$ & $26.6(1.8)$ & $14.1(6.4)$ & $20.4(0.1)$ \\
\hline 16:1 trans 9 & & & $6.8(1.5)$ & $5.0(0.7)$ & & & $1.1(1.4)$ \\
\hline $16: 0$ & $26.4(1.6)$ & $25.1(2.2)$ & $11.9(0.2)$ & $13.1(1.1)$ & $17.3(2.7)$ & $17.2(4.3)$ & $26.7(0.5)$ \\
\hline $16: 12-\mathrm{OH}$ & & $0.3(0.2)$ & & & & & \\
\hline $16: 03-\mathrm{OH}$ & $0.5(0.3)$ & & & & & $7.9(2.6)$ & \\
\hline $17: 0$ iso & & & & $1.0(0.2)$ & $0.5(0.1)$ & & \\
\hline 17:0 cyclo & $5.0(2.6)$ & $2.3(1.2)$ & & $1.6(0.3)$ & $0.5(0.1)$ & $2.6(0.6)$ & $10.6(3.5)$ \\
\hline $17: 1 \mathrm{~B}$ & & & $1.3(0.1)$ & $0.8(0.4)$ & & & \\
\hline $17: 1 \mathrm{C}$ & & & $1.1(0.2)$ & & & & \\
\hline $17: 0$ & & & $0.3(0)$ & $0.6(0.3)$ & & & $\operatorname{tr}$ \\
\hline $18: 1$ cis 11 & $17.1(1.4)$ & $22.4(2.9)$ & $35.6(1.1)$ & $41.6(2.7)$ & $38.4(0.5)$ & $22.7(2.8)$ & $16.2(0.4)$ \\
\hline $18: 0$ & $0.6(0.2)$ & $1.1(0.1)$ & $0.2(0.1)$ & $0.4(0)$ & $0.4(0.1)$ & $0.5(0.1)$ & $0.5(0)$ \\
\hline 19:0 cyclo $9-10$ & & & & & & $0.4(0.3)$ & \\
\hline 19:0 cyclo $11-12$ & $0.5(0.4)$ & & & $0.3(0.5)$ & $0.9(0)$ & $0.2(0.2)$ & $0.2(0.1)$ \\
\hline UNK 19.368 & & & & & & $4.7(2.4)$ & \\
\hline
\end{tabular}

\footnotetext{
${ }^{a}$ tr, trace amounts are present in some strains.
} 


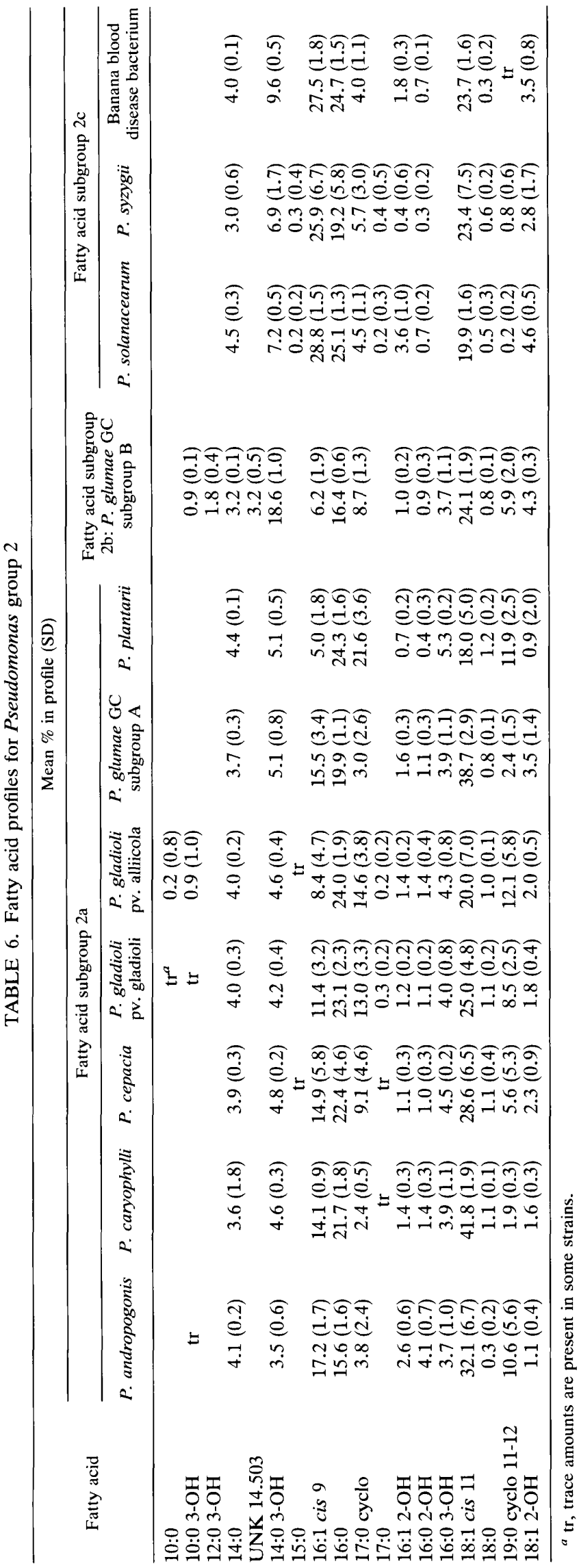

group the core hydroxy acids were 14:0 3-OH, 16:1 2-OH, and 18:1 2-OH. In addition, most strains contained 16:0 2-OH, and all strains except strains of $P$. solanacearum and its close relatives also contained 16:0 3-OH.

Ten taxa were included in group 2 . Three subgroups were differentiated. $P$. glumae strains produced two different profiles, both belonging to group 2 .

The nonhydroxy acids were similar to those found in group 1 profiles. The major differences were the absence of 12:0 and relatively greater amounts of 14:0 and 19:0 cyclo 11-12.

(i) Subgroup 2a. Subgroup 2a contained $P$. andropogonis, $P$. caryophylli, $P$. cepacia, $P$. gladioli pv. gladioli, $P$. gladioli pv. alliicola, $P$. plantarii, and some strains of $P$. glumae, including strain NCPPB $2981^{\mathrm{T}}$ ( $\mathrm{T}=$ type strain). An unusual feature of subgroup 2a was the variation in the amounts of several fatty acids (notably, 16:1 cis 9, 18:1 cis 11, 17:0 cyclo, and 19:0 cyclo 11-12). All of the taxa except $P$. caryophylli showed this variation. The variation was greatest for $P$. gladioli pv. alliicola. For example, in $P$. gladioli the values for $16: 1 \mathrm{cis} 9$ ranged from 3.2 to $11.4 \%$, the values for 17:0 cyclo ranged from 3.3 to $14.6 \%$, and the values for $18: 1$ cis 11 ranged from 4.8 to $25.0 \%$. The profiles of most of the taxa were qualitatively similar; the exceptions were some $P$. gladioli pv. alliicola strains, which contained 10:0 and 10:0 3-OH.

The $P$. glumae strains included in subgroup 2a were the type strain (strain NCPPB 2981) and strains ICMP 3728 and ICMP 3729. The profiles of these strains were quite similar to those of $P$. cepacia.

(ii) Subgroup 2b. Subgroup $2 \mathrm{~b}$ contained $P$. glumae NCPPB 2391 and NCPPB 3591. The two strains in this subgroup were unusual in that they contained significant amounts of 10:0 3-OH and were unique in group 2 because they contained 12:0 3-OH. The quantities of $14: 03-\mathrm{OH}$ were much higher than the quantity of 14:0 3-OH for any other member of group 2. These strains also contained an unknown branched hydroxy acid (equivalent chain length, 14.503) at levels of 2 to $4 \%$.

(iii) Subgroup 2c. Subgroup 2c contained $P$. solanacearum, $P$. syzygii, and the banana blood disease bacterium. This subgroup was readily differentiated by the absence of $16: 0$ 3-OH. Some strains also lacked 16:0 2-OH. The 49 strains of $P$. solanacearum which were studied included strains belonging to all three races and biovars I, II, III, and IV. All of the strains in subgroup $2 \mathrm{c}$ had very similar profiles.

Group 3. Species in group 3 were differentiated by having only a single core hydroxy acid, 10:0 3-OH (Table 7), although some strains contained small amounts of other hydroxy acids, including 12:1 3-OH, 12:0 3-OH, 14:0 2-OH, 14:0 3-OH, 15:0 2-OH, 16:1 2-OH, and 16:0 2-OH. The nonhydroxy fatty acids were very similar to those of group 1 , although the levels of 14:0 and 16:0 were usually higher in the group 3 strains.

Two subgroups were recognized, and they were differentiated by their hydroxy fatty acids. Subgroup 3b strain profiles contained several 2-hydroxy acids in addition to the core acid, 10:0 3-OH.

(i) Subgroup 3a. Subgroup 3a contained C. acidovorans, $P$. avenae, $P$. rubrilineans, $P$. pseudoalcaligenes subsp. citrulli, $P$. pseudoalcaligenes subsp. konjaci, and type strain NCPPB 961 of $P$. cattleyae. The major hydroxy acid was 10:0 3-OH. Small amounts of other 3-hydroxy acids occurred in most strains, but no 2-hydroxy acids were found.

$P$. pseudoalcaligenes subsp. citrulli and $P$. pseudoalcaligenes subsp. konjaci had a group 3 profile similar to that of 
TABLE 7. Fatty acid profiles for Pseudomonas group 3 species, including Comamonas spp.

\begin{tabular}{|c|c|c|c|c|c|c|c|}
\hline \multirow{3}{*}{ Fatty acid } & \multicolumn{7}{|c|}{ Mean $\%$ in profile $(\mathrm{SD})$} \\
\hline & \multicolumn{6}{|c|}{ Fatty acid subgroup $3 a$} & \multirow{2}{*}{$\begin{array}{c}\text { Fatty acid } \\
\text { subgroup } 3 \mathrm{~b}: \\
\text { C. testosteroni }\end{array}$} \\
\hline & C. acidovorans & $P$. avenae & $\begin{array}{l}\text { P. cattleyae } \\
\text { NCPPB } 961^{\mathrm{T}}\end{array}$ & $\begin{array}{l}\text { P. pseudoalcaligenes } \\
\text { subsp. citrulli }\end{array}$ & $\begin{array}{l}\text { P. pseudoalcaligenes } \\
\text { subsp. konjaci }\end{array}$ & P. rubrilineans & \\
\hline $10: 0$ & & $0.2(0.2)$ & $\operatorname{tr}^{a}$ & & $\operatorname{tr}$ & $0.2(0.1)$ & $\operatorname{tr}$ \\
\hline 10:0 3-OH & $2.8(0.1)$ & $3.1(1.0)$ & $3.7(0.2)$ & $3.4(0.3)$ & $3.2(0.2)$ & $3.3(0.4)$ & $3.5(0.7)$ \\
\hline $12: 0$ & $2.6(0.2)$ & $2.5(0.7)$ & $2.3(0.1)$ & $2.4(0.1)$ & $2.7(0.1)$ & $2.3(0.2)$ & $2.3(0.2)$ \\
\hline $12: 13-\mathrm{OH}$ & & & $0.6(0.1)$ & $\operatorname{tr}$ & & & \\
\hline $14: 0$ & $0.7(0.2)$ & $2.4(0.8)$ & $1.7(0.1)$ & $1.6(0.2)$ & $3.1(0.1)$ & $2.1(0.2)$ & $0.2(0.1)$ \\
\hline 14:0 2-OH & & & & & & & $0.3(0.1)$ \\
\hline 14:0 3-OH & & $0.9(1.8)$ & & & & $0.4(0.5)$ & \\
\hline $15: 1 \mathrm{~B}$ & & & & $1.5(0.7)$ & & & \\
\hline $15: 0$ & $1.9(1.8)$ & $0.3(0.4)$ & $0.5(0.1)$ & $5.2(1.8)$ & $\operatorname{tr}$ & $0.3(0.1)$ & $0.8(0.4)$ \\
\hline $15: 02-\mathrm{OH}$ & & & & & & & $0.2(0.1)$ \\
\hline $16: 1$ cis 9 & $36.4(4.3)$ & $41.4(3.8)$ & $40.6(0.3)$ & $42.1(0.5)$ & $43.9(0.3)$ & $43.2(1.9)$ & $32.5(2.4)$ \\
\hline $16: 0$ & $32.0(1.2)$ & $31.9(2.0)$ & $34.9(0.4)$ & $33.1(2.5)$ & $28.3(1.5)$ & $32.2(1.4)$ & $29.1(2.4)$ \\
\hline 17:0 cyclo & $6.3(3.6)$ & $0.8(1.1)$ & $0.5(0.2)$ & & & $0.2(0.2)$ & $4.4(1.9)$ \\
\hline $16: 12-\mathrm{OH}$ & & & & & & & $1.2(0.9)$ \\
\hline $16: 02-\mathrm{OH}$ & & & & & & & $2.7(0.2)$ \\
\hline $17: 0$ & $0.7(0.9)$ & $\operatorname{tr}$ & $0.2(0.2)$ & $1.3(0.4)$ & & $\operatorname{tr}$ & $1.2(0.7)$ \\
\hline $18: 1$ cis 11 & $16.0(2.0)$ & $15.5(2.0)$ & $14.4(0.6)$ & $9.1(1.5)$ & $18.3(1.4)$ & $15.0(1.8)$ & $19.9(1.8)$ \\
\hline $18: 0$ & $\operatorname{tr}$ & $0.2(0.1)$ & $0.2(0.2)$ & & & $0.3(0.1)$ & $0.4(0.1)$ \\
\hline 19:0 cyclo $11-12$ & & & & & & & $0.7(0.1)$ \\
\hline
\end{tabular}

${ }^{a}$ tr, trace amounts are present in some strains.

$P$. acidovorans (Pseudomonas section III, rRNA superfamily III), whereas $P$. pseudoalcaligenes subsp. pseudoalcaligenes had a group 1 profile (Pseudomonas section I, rRNA superfamily II).

(ii) Subgroup 3b. Subgroup 3b contained C. testosteroni. Only two strains, including the type strain, were available. These two strains produced very similar profiles, which included small amounts of several 2-hydroxy acids (14:0 2-OH, 16:1 2-OH, and 16:0 2-OH). One strain repeatedly produced small amounts of 15:0 2-OH.

Group 4. Group 4 contained $S$. paucimobilis. The only hydroxy acid present in group 4 was 14:0 2-OH (Table 8). The profile was relatively simple, primarily consisting of $16: 1$ cis $9,16: 0,17: 0$ cyclo, and 18:1 cis 11 , which was by far the dominant acid $(>60 \%)$.

$S$. paucimobilis is common on plant surfaces but is not regarded as a plant pathogen.

Group 5. Group 5 contained $P$. flectens. The group 5 profile contained three hydroxy acids, 12:0 2-OH, 14:0 2-OH, and 14:0 3-OH (Table 8). The other major acids included 12:0, 14:0, 16:1 cis 9, 16:0, 17:0 cyclo, and 18:1 cis 11. The type strain of $P$. flectens (strain NCPPB 539) had a profile which contained many iso- and anteiso-branched acids. However, examination of the same strain obtained from the International Collection of Microorganisms from Plants (ICMP) (strain ICMP 745) showed that it had the same profile type as strains NCPPB 538 and ICMP 127.

Group 6. Group 6 contained $P$. betle, $P$. cissicola, $P$. hibiscicola, $P$. maltophilia, and Xanthomonas campestris pv. campestris. The group 6 profiles were very different from those of groups 1 through 5 and are shown in Table 8 . The major feature that differentiated this group was the presence of large amounts of iso- and anteiso-branched acids in the profiles, in particular 15:0 iso and 15:0 anteiso. Many strains contained 10:0 3-OH and 12:0 3-OH, the two core acids of group 1, and all strains contained 11:0 iso $3-\mathrm{OH}$ and 13:0 iso 3-OH. Trace amounts of several other hydroxy acids were also present. Although there were obvious differences in the profiles of some of these taxa, there were no obvious subgroupings based on quantitative differences in the hydroxy acids, although there were quantitative differences for P. cissicola.

\section{DISCUSSION}

In this study I demonstrated the taxonomic value of the 2and 3-hydroxy and branched 3-hydroxy fatty acids for differentiating plant-pathogenic and other bacteria belonging to the genus Pseudomonas. Most of these acids were present at levels less than $5 \%$ of the total fatty acid peak area, and although three or four hydroxy acids were often present in a profile, the total was usually less than $10 \%$ of the total peak area. The single exception was $P$. amygdali, which contained more than $20 \%$ hydroxy fatty acids, the majority of which was 10:0 3-OH. The classification of the strains which I studied into six clearly defined groups is shown in Table 9. The nonhydroxy fatty acids, although much more abundant, were of value for differentiating species, but they were generally of less value for differentiating major groups (Tables 3 through 8 ). All of the strains included in this study contained 16:0, 16:1 cis, and 18:1 cis 11. These were often the most abundant fatty acids present in profiles and are known to be major inner membrane constituents of most if not all gram-negative bacteria (21). Nevertheless, quantitative differences in these and other nonhydroxy fatty acids were of value for differentiating between taxa within groups. All of the fluorescent pseudomonads fell into group 1 , which had two core hydroxy acids (10:0 3-OH and 12:0 3-OH). In addition, all of the strains except the subgroup 1d strains contained 12:0 2-OH. Group 3 strains had the most similar profiles, differing primarily in the absence of $12: 02-\mathrm{OH}$ and 12:0 3-OH. Group 2 strains were completely different since all of the hydroxy acids present contained 14, 16, and 18 carbon atoms. Occasional strains contained additional minor hydroxy fatty acids. Group 4 strains contained only 14:0 2-OH, whereas group 5 strains also contained 12:0 2-OH and 
TABLE 8. Fatty acid profiles for Pseudomonas group 4, 5, and 6 species and $X$. campestris pv. campestris

\begin{tabular}{|c|c|c|c|c|c|c|c|}
\hline \multirow{3}{*}{ Fatty acid } & \multicolumn{7}{|c|}{ Mean \% in profile (SD) } \\
\hline & \multirow{2}{*}{$\begin{array}{l}\text { Fatty acid group } 4: \\
\text { S. paucimobilis }\end{array}$} & \multirow{2}{*}{$\begin{array}{l}\text { Fatty acid group } \\
\text { 5:P. flectens }\end{array}$} & \multicolumn{5}{|c|}{ Fatty acid group 6} \\
\hline & & & P. betle & P. cissicola & P. hibiscicola & $\begin{array}{l}X . \text { campestris } \\
\text { pv. campestris }\end{array}$ & $X$. maltophilia \\
\hline UNK 9.521 & & & $0.5(0.2)$ & & $0.2(0.3)$ & & $\operatorname{tr}^{a}$ \\
\hline $10: 0$ & & $0.1(0.1)$ & $0.9(0.4)$ & & $0.5(0)$ & $1.0(0.1)$ & $0.6(0.1)$ \\
\hline $11: 0$ iso & & & $4.6(2.1)$ & $0.9(0.2)$ & $3.3(0.1)$ & $3.1(0.2)$ & $3.2(0.2)$ \\
\hline 10:0 3-OH & & & $\operatorname{tr}$ & $1.7(0.4)$ & $\operatorname{tr}$ & $0.2(0.1)$ & $\operatorname{tr}$ \\
\hline UNK 11.798 & & & $1.6(0.6)$ & $1.8(0.3)$ & $1.4(0)$ & $1.4(0.1)$ & $1.4(0.1)$ \\
\hline $11: 0$ iso $3-\mathrm{OH}$ & & & $1.6(0.1)$ & $2.7(0.4)$ & $1.6(0)$ & $2.0(0.2)$ & $1.5(0.1)$ \\
\hline $13: 0$ iso & & & $0.7(0.3)$ & $0.2(0.2)$ & $0.5(0.1)$ & $\operatorname{tr}$ & $0.5(0.1)$ \\
\hline $12: 02-\mathrm{OH}$ & & $1.1(0.1)$ & & $\operatorname{tr}$ & & & \\
\hline $12: 03-\mathrm{OH}$ & & & $2.5(0.1)$ & $1.0(0.1)$ & $2.5(0.1)$ & $3.6(0.6)$ & $2.9(0.4)$ \\
\hline $14: 0$ iso & & & $1.0(0.1)$ & $\operatorname{tr}$ & $0.5(0.1)$ & $\operatorname{tr}$ & $1.4(0.8)$ \\
\hline UNK 13.961 & & $0.8(0.4)$ & & & & & \\
\hline $14: 0$ & $0.6(0.2)$ & $2.6(0.2)$ & $5.2(0.2)$ & $2.5(0.2)$ & $3.3(0.4)$ & $1.4(0.2)$ & $4.1(0.8)$ \\
\hline $13: 0$ iso $3-\mathrm{OH}$ & & & $2.5(0.1)$ & $1.8(0.2)$ & $3.1(0.2)$ & $2.8(0.2)$ & $2.8(0.7)$ \\
\hline 13:0 2-OH & & & $0.2(0.2)$ & $\operatorname{tr}$ & $0.3(0.1)$ & $\operatorname{tr}$ & $0.4(0.3)$ \\
\hline $15: 1$ iso $F$ & & & $1.3(0.3)$ & $0.4(0.4)$ & $1.1(0.1)$ & $0.3(0.3)$ & $1.1(0.1)$ \\
\hline UNK 14.503 & & $0.8(0.2)$ & & & & & \\
\hline $15: 0$ iso & & & $35.1(1.1)$ & $32.3(5.5)$ & $39.2(2.6)$ & $21.2(1.6)$ & $33.9(3.3)$ \\
\hline 15:0 anteiso & & & $12.9(0.6)$ & $5.8(0.8)$ & $10.0(2.1)$ & $12.1(0.3)$ & $13.2(3.2)$ \\
\hline $15: 0$ & $\operatorname{tr}$ & & $0.5(0.1)$ & $1.0(0.2)$ & $0.4(0)$ & $1.2(0.2)$ & $0.8(0.4)$ \\
\hline $14: 02-\mathrm{OH}$ & $7.7(1.3)$ & $3.5(0.3)$ & & & & & \\
\hline 14:0 3-OH & & $8.8(1.4)$ & & & & & \\
\hline $16: 0$ iso & & & $1.1(0.2)$ & $0.8(0.2)$ & $0.9(0.3)$ & $1.9(0.4)$ & $1.6(0.6)$ \\
\hline $16: 1 \mathrm{~B}$ & & & $3.4(0.1)$ & $2.0(0.5)$ & $3.1(0.1)$ & $2.8(0.4)$ & $3.3(0.3)$ \\
\hline $16: 1$ cis 9 & $8.2(1.3)$ & $34.2(2.2)$ & $12.0(0.1)$ & $25.1(3.0)$ & $12.4(0.1)$ & $18.3(0.8)$ & $12.1(1.0)$ \\
\hline $16: 1 \mathrm{C}$ & $0.5(0.1)$ & $0.2(0.1)$ & & $0.1(0.3)$ & & & \\
\hline $16: 0$ & $14.0(1.8)$ & $37.6(1.7)$ & $4.8(1.1)$ & $8.3(4.5)$ & $5.2(0.3)$ & $8.2(0.7)$ & $5.8(0.7)$ \\
\hline $17: 1$ iso $F$ & & & $3.9(0.6)$ & $4.2(1.4)$ & $4.5(0.2)$ & $6.3(0.7)$ & $3.7(1.1)$ \\
\hline $17: 0$ iso & & & $1.7(0.6)$ & $4.6(1.5)$ & $3.1(0.1)$ & $7.4(0.7)$ & $2.4(0.6)$ \\
\hline $17: 0$ anteiso & & & & & & $0.8(0.1)$ & $0.2(0.1)$ \\
\hline $17: 1 \mathrm{~B}$ & & & $\operatorname{tr}$ & $0.3(0.3)$ & $0.2(0)$ & $1.1(0.2)$ & $0.2(0.1)$ \\
\hline $17: 1 \mathrm{C}$ & $1.0(0.7)$ & & & & & $\operatorname{tr}$ & \\
\hline 17:0 cyclo & $\operatorname{tr}$ & $3.3(2.4)$ & & & & & $\operatorname{tr}$ \\
\hline $18: 1$ cis 9 & & & $0.7(0.2)$ & $0.2(0.3)$ & $1.2(0.1)$ & $0.8(0.1)$ & $1.1(0.2)$ \\
\hline $18: 1$ cis 11 & $65.2(1.0)$ & $4.1(1.0)$ & $0.3(0.3)$ & $1.8(2.8)$ & $0.8(0.1)$ & $0.8(0.2)$ & $0.7(0.3)$ \\
\hline $18: 1 \mathrm{~B}$ & $1.1(0.2)$ & & & & & & \\
\hline 18:0 & $0.8(0.2)$ & $0.1(0.1)$ & & $0.1(0.2)$ & & & $\operatorname{tr}$ \\
\hline
\end{tabular}

${ }^{a} \mathrm{tr}$, trace amounts are present in some strains.

14:0 3-OH. In most other respects the profiles of groups 1,3 , and 4 were qualitatively similar. The dominant fatty acids were 16:0,16:1 cis 9, and 18:1 cis 11 . Group 1 and 3 strains contained significant amounts of 12:0, whereas group 2,4 , and 5 strains contained few if any nonhydroxy fatty acids that contained less than 14 carbon atoms.

Group 6 strains had a completely different profile type. Not only was this group the only group to contain branched hydroxy fatty acids (11:0 iso $3-\mathrm{OH}$ and 13:0 iso $3-\mathrm{OH}$ ) in addition to $12: 03-\mathrm{OH}$, but all of the group 6 strains also contained more than $50 \%$ branched nonhydroxy fatty acids $(11,13,15$, and 17 carbon atoms).

Groups 1, 2, and 3 were further subdivided on the basis of the presence of other more minor hydroxy fatty acids (subgroups 1a, 1b, 1c, 1e, 2a, 2b, and 3b) or on the basis of quantitative differences in the core hydroxy fatty acids (subgroup 1f).

Some nonhydroxy fatty acids were of value for differentiating some of the groups. The most obvious examples were the branched acids, in particular 15:0 iso, 15:0 anteiso, 17:0 iso $F$, and 17:0 iso in group 6 . These fatty acids were not found in any of the other groups except for small amounts of 17:0 iso in some group 1 taxa. Most group 2 strains had no fatty acids with less than 14 carbon atoms. Most of the unsaturated fatty acids were cis isomers, although a few group 1 taxa contained significant amounts of 16:1 trans 9 (for example, $P$. aeruginosa, $P$. putida biovar A, $P$. alcaligenes, and $P$. pseudoalcaligenes subsp. pseudoalcaligenes).

The cyclopropane fatty acids also were of some value for differentiating species. Within subgroup $1 \mathrm{a}, P$. fluorescens and its close relatives (Table 4) had significantly higher levels of 17:0 cyclo than $P$. syringae and its close relatives (Table 3). Likewise, 19:0 cyclo 11-12 was much more abundant in subgroup $2 \mathrm{a}$ and $2 \mathrm{~b}$ taxa than in group 1 and subgroup $2 \mathrm{c}$ taxa. This fatty acid also differentiated subgroup $3 \mathrm{a}$ from subgroup 3b. It was not found in any group 4, 5, or 6 taxa.

Differentiation of taxa at specific and infraspecific levels. The results in Tables 3 through 8 show that many species have unique profiles. Some infraspecific taxa (subspecies, biovar, pathovar) also have unique profiles. Differences at and below the specific level were usually quantitative and were sometimes found for several acids in the profile. Occasionally, qualitative differences were found; for example, of the $P$. syringae strains tested, only $P$. syringae pv. phaseolicola strains contained 16:0 3-OH. Thus, within each subgroup most taxa could be differentiated. 
TABLE 9. Grouping of strains according to the presence of hydroxy fatty acids in their profiles

\begin{tabular}{|c|c|c|c|c|c|c|c|c|c|c|c|}
\hline \multirow{2}{*}{$\begin{array}{l}\text { Fatty acid group } \\
\text { or subgroup }\end{array}$} & \multicolumn{11}{|c|}{ Presence of the following hydroxy fatty acids: } \\
\hline & $\begin{array}{c}\text { 10:0 } \\
\text { 3-OH }\end{array}$ & $\begin{array}{c}12: 0 \\
2-\mathrm{OH}\end{array}$ & $\begin{array}{c}\text { 12:0 } \\
\text { 3-OH }\end{array}$ & $\begin{array}{c}14: 0 \\
2-\mathrm{OH}\end{array}$ & $\begin{array}{c}14: 0 \\
3-\mathrm{OH}\end{array}$ & $\begin{array}{c}16: 1 \\
2-\mathrm{OH}\end{array}$ & $\begin{array}{c}16: 0 \\
2-\mathrm{OH}\end{array}$ & $\begin{array}{c}16: 0 \\
3-\mathrm{OH}\end{array}$ & $\begin{array}{c}18: 1 \\
2-\mathrm{OH}\end{array}$ & $\begin{array}{c}11: 0 \text { iso } \\
3-\mathrm{OH}\end{array}$ & $\begin{array}{c}13: 0 \text { iso } \\
3-\mathrm{OH}\end{array}$ \\
\hline $1 \mathrm{a}^{a}$ & $+^{b}$ & + & + & & $(+)$ & & & $(+)$ & & & \\
\hline $1 b$ & + & + & + & & + & & & + & & & \\
\hline $1 c$ & + & + & + & + & & + & & & & & \\
\hline $1 \mathrm{~d}$ & + & & + & & & & & & & & \\
\hline le & + & + & + & & $(+)$ & & & + & & & \\
\hline $1 f^{a}$ & + & + & + & & & & & & & & \\
\hline $2 a$ & & & & & + & + & + & + & + & & \\
\hline $2 b$ & + & & + & & + & + & + & + & + & & \\
\hline $2 c$ & & & & & + & $(+)$ & & + & + & & \\
\hline $3 a$ & + & & & & & & & & & & \\
\hline $3 b$ & + & & & + & & + & + & & & & \\
\hline 4 & & & & + & & & & & & & \\
\hline 5 & & + & & + & + & & & & & & \\
\hline 6 & $(+)$ & & + & & & & & & & + & + \\
\hline
\end{tabular}

a Differentiation of subgroups $1 \mathrm{a}$ and $1 \mathrm{f}$ was not based on qualitative differences in hydroxy acids.

$b+$, present; $(+)$, some taxa or strains contain small quantities.

Group 1. Subgroup la was by far the largest subgroup. All of the other subgroups except subgroup Id contained single taxa. Subgroup la contained all of the fluorescent pseudomonads. The profiles of the strains belonging to each taxon showed little variation. However, alteration of the cultural conditions increased variation. For example, 17:0 cyclo levels increased with increasing age (26).

The data for all of the subgroup la taxa with a mean value for 12:0 2-OH of less than 3\% are shown in Table 3, and the data for most of the subgroup 1a taxa with a mean value for 12:0 2-OH of more than $4 \%$ are shown in Table 4 (the single exception is $P$. fluorescens biovar 4 [mean value, $2.2 \%$ ]). Further analysis demonstrated other differences between the bacteria listed in Tables 3 and 4. Most of the taxa included in Table 3 contained significantly higher levels of the unsaturated acids 16:1 cis 9 and 18:1 cis 11 (52 to 60\%) than the taxa included in Table 4 (36 to 47\%); the exceptions were $P$. aeruginosa $(54.8 \%)$ and the two plant pathogens $P$. asplenii $(51.9 \%)$ and $P$. fuscovaginae (52.4\%). This subdivision also parallelled the subdivision based on the ratio of $16: 0$ to $16: 1$ cis 9 . This ratio was less than 0.9 for all bacteria included in Table 3 plus the plant pathogens $P$. asplenii and $P$. fuscovaginae and greater than 0.9 for all of the other bacteria included in Table 4.

$P$. aeruginosa had the highest ratio by far. Likewise, $P$. syringae and its close relatives included in Table 3 usually contained small but consistent amounts of 19:0 cyclo 9-10, whereas none of the bacteria included in Table 4 contained this fatty acid. Most of these bacteria contained a different isomer, 19:0 cyclo 11-12. Only occasional strains of $P$. syringae pv. phaseolicola contained both isomers. In addition, the bacteria listed in Tables 3 and 4 could be further differentiated on the basis of the amounts of another cyclopropane fatty acid, 17:0 cyclo. $P$. syringae and its relatives contained 0 to $2 \% 17: 0$ cyclo, whereas $P$. fluorescens and its relatives listed in Table 4 contained 1.9 to $13.9 \%$. $P$. aeruginosa contained only trace amounts of this fatty acid.

Thus, subgroup la comprised three well-defined profile types, represented by $P$. aeruginosa, $P$. syringae, and $P$. fluorescens. All of the plant-pathogenic species tended to have profiles very similar to the profile of $P$. syringae pv. syringae (e.g., 12:0 2-OH, <3\%; 16:1 cis $9+18: 1$ cis 11 , $>52 \%$; ratio of $16: 0$ to $16: 1$ cis $9,<0.9$ ).
Within subgroup 1a, the largest subgroup, there were some obvious differences among some taxa even at pathovar and biovar levels for $P$. syringae and $P$. fluorescens, respectively. For example, $P$. syringae pv. tomato had a much simpler profile with fewer fatty acids than $P$. syringae pv. phaseolicola. $P$. fluorescens biovar 4 had a profile that was readily distinguished from the profiles of the other $P$. fluorescens biovars. Fatty acids with obvious diagnostic value included 12:0, 12:0 2-OH, 16:1 cis 9, 16:0, 17:0 cyclo, 18:1 cis 11, 19:0 cyclo 9-10, and 19:0 cyclo 11-12.

For some taxa within subgroup 1a, no significant differences were found. For example, $P$. fluorescens biovar $1, P$. fluorescens biovar 2, $P$. fluorescens biovar 5, $P$. marginalis pv. marginalis, $P$. marginalis pv. alfalfae, and $P$. marginalis pv. pastinacae had very similar profiles. $P$. syringae pv. tomato and $P$. viridiflava also had very similar profiles. Further studies with larger numbers of strains and analysis under different cultural conditions will be required to determine whether these taxa can be differentiated by their fatty acid profiles.

Subgroup 1 b contained a single species, $P$. corrugata. Most strains contained a series of additional minor hydroxy fatty acids (namely, 12:1 3-OH, 14:0 3-OH, 16:0 3-OH, and unknown fatty acids with equivalent chain lengths of 13.961 and 14.503). The values for these fatty acids never exceeded $2.0 \%$ of the total fatty acids. The two unknown fatty acids were confirmed as hydroxy acids by mass spectrometry. They contained 13 and 14 carbon atoms, respectively. For both, the hydroxy group was not in the 2 or 3 position.

Subgroup 1c also contained a single species, $P$. rubrisubalbicans, which was differentiated by the presence of 14:02-OH and 16:0 2-OH. 14:0 2-OH is not commonly found in bacteria; the only other bacteria in this study which contained it were $C$. testosteroni, $S$. paucimobilis, and $P$. flectens.

Subgroup 1d contained three taxa, $P$. alcaligenes, $P$. pseudoalcaligenes subsp. pseudoalcaligenes, and $P$. stutzeri. The subgroup 1d strains contained no or just trace amounts of 12:0 2-OH, which differentiated them from all other group 1 strains. The three taxa were readily differentiated from each other. $P$. alcaligenes contained significantly more $10: 0$ and $17: 1 \mathrm{C}$ than the other two taxa. $P$. stutzeri did not contain 16:1 trans $9,15: 0,17: 1 \mathrm{~B}$, or 17:0.

Subgroup le contained $P$. amygdali, which was differen- 
tiated from subgroup 1a strains solely on the basis of quantitative differences in hydroxy fatty acids. $P$. amygdali is a very slowly growing bacterium, and in this study 7-day cultures were required to obtain enough cells for analysis. Further study will be required to determine to what extent the profile differences between this organism and other bacteria in subgroup 1a are due to cultural conditions, such as culture age. Preliminary results (data not shown) have indicated that culturing $P$. syringae for 7 days does not dramatically increase the percentage of hydroxy fatty acids.

Subgroup if contained a single strain, $P$. cattleyae NCPPB 1874. The $P$. cattleyae type strain (strain NCPPB 961) was placed in group 3 and is discussed below.

Group 2. One of the most interesting features of group 2 was the variation found in the profiles of most subgroup $2 \mathrm{a}$ taxa. For $P$. gladioli pv. alliicola this variation was linked to colony morphology. Smooth colonies produced profiles which contained no 10:0 or 10:0 3-OH, whereas colonies with rippled surfaces consistently produced these acids. Other acids for which variation occurred in $P$. gladioli included $16: 1$ cis $9,18: 1$ cis 11 , and 17:0 cyclo. This variation is an unusual phenomenon since there appeared to be a continuum across the ranges of values rather than two or more discrete GC groups. This variation made it more difficult to identify obvious differences in the taxa belonging to subgroup $2 \mathrm{a}$. $P$. andropogonis, $P$. caryophylli, $P$. glumae GC subgroup A, and $P$. plantarii were readily differentiated, whereas differences among $P$. cepacia, $P$. gladioli pv. gladioli, and $P$. gladioli pv. alliicola were less obvious. There were no differences in the profiles of the strains received as $P$. woodsii, $P$. stizolobii, and $P$. andropogonis, which supported a previous proposal of synonymy with $P$. andropogonis (14).

Subgroup 2b comprised two strains of $P$. glumae, which contained significant amounts of 10:0 3-OH and 12:0 3-OH. These two strains were unique in having the core hydroxy acids of both groups 1 and 2 . They also contained an unknown branched hydroxy fatty acid with an equivalent chain length of 14.503 . This fatty acid also occurs in $P$. corrugata (subgroup 1b) and in many members of the Enterobacteriaceae (unpublished data). All of the cultures of $P$. glumae which were tested were isolated from rice in Japan. At the present time no further phenetic studies have been carried out to substantiate the differences shown in the fatty acid profiles.

The absence of 16:0 3-OH clearly differentiated $P$. solanacearum, $P$. syzygii, and the banana blood disease bacterium from other group 2 members. As with $P$. amygdali, $P$. syzygii and the banana blood disease bacterium are slow growers and were taken from 6- and 2-day cultures, respectively. $P$. syzygii in particular exhibited great quantitative variation in its profiles, and this made it difficult to differentiate it from the other two taxa. Considering the great differences in the growth rates, the different culture media, and the phenotypic differences between $P$. syzygii and $P$. solanacearum (22), the profiles were remarkably similar. Further studies will be required to determine whether fatty acid profiles can differentiate any of these three taxa. The $P$. solanacearum strains selected also included all three known races and four of the five known biovars. No differences in the profiles were detected under the cultural conditions which I used.

Group 3. Most group 3 strains were unusual in that they contained only a single hydroxy fatty acid (10:0 3-OH), which accounted for only 2 to $4 \%$ of the total fatty acid peak area. Only the absence of 12:0 2-OH and 12:0 3-OH differ- entiated these strains from most group 1 strains. The nonhydroxy fatty acid components of the profiles were even quantitatively similar to those of group 1 . Some $P$. avenae and $P$. rubrilineans strains contained small amounts of $14: 0$ 3-OH. $P$. cattleyae NCPPB $961^{\mathrm{T}}$ contained small amounts of 12:1 3-OH. In addition to 10:0 3-OH, C. testosteroni contained significant amounts of 16:1 2-OH and 16:0 2-OH and on this basis was placed in a separate subgroup. Some subgroup 3 a taxa were readily differentiated. $P$. pseudoalcaligenes subsp. citrulli and $P$. pseudoalcaligenes subsp. konjaci were clearly differentiated from $P$. pseudoalcaligenes subsp. pseudoalcaligenes, which was placed in subgroup 1d. Confusion between $P$. pseudoalcaligenes and some bacteria now included in the family Comamonadaceae (33) is common because of a lack of convenient differential phenotypic characters (34). This perhaps accounts for the misnaming of these two plant pathogens, which clearly exhibit greater similarity to the other strains of the Comamonadaceae (34) included in this study. They differ from the two Comamonas spp. in their significantly greater amounts of 14:0 and 16:1 cis 9. They are readily differentiated from each other by the absence in $P$. pseudoalcaligenes subsp. konjaci of 15:0, 15:1 B, and 17:0 and in the higher amounts of 14:0 and 18:1 cis 11 . In contrast, $P$. avenae and $P$. rubrilineans could not be differentiated, supporting recent evidence of synonymy $(3,20)$, since no major differences in nutritional, physiological, serological, or host assays were detected. The results of recent studies on the genus Comamonas (34) suggest that although the plant-pathogenic strains belonging to group 3 belong to the family Comamonadaceae, they are not members of the genus Comamonas.

Group 4. Group 4 contained a single species, which has been reclassified as $S$. paucimobilis (35). Other workers (7, 15) have found that this organism is not closely related to other Pseudomonas spp. but is closely related to the misnamed organism Flavobacterium capsulatum, which has also been reclassified in the genus Sphingomonas (35). S. paucimobilis is unusual in having 14:0 $2-\mathrm{OH}$ as the sole hydroxy fatty acid. Few gram-negative bacteria completely lack 3-hydroxy fatty acids. Other recent evidence also indicates that $S$. paucimobilis has a fatty acid profile similar to that of Rhizomonas suberifaciens, a newly described taxon that causes corky root of tomato (31).

Group 5. The type strain of $P$. flectens (strain NCPPB 539) had a profile which contained many branched acids and was different from the profiles of the other strains tested. It proved to be a gram-positive bacterium. However, examination of the same strain obtained as strain ICMP 745 showed that it had the same profile as the other $P$. flectens strains. Therefore, it must be assumed that contamination of strain NCPPB $539^{T}$ occurred. The only other bacteria which I know of which contain 12:0 3-OH, 14:0 2-OH, and 14:0 $3-\mathrm{OH}$ are some Alcaligenes and Serratia strains. The nonhydroxy part of the profile was most consistent with the profile of the genus Alcaligenes (unpublished data).

Group 6. All group 6 strains produced large amounts of branched acids and were the only bacteria in this study to do so. All of the strains also contained three core hydroxy fatty acids, 12:0 $3-\mathrm{OH}, 11: 0$ iso $3-\mathrm{OH}$, and 13:0 iso $3-\mathrm{OH}$. The inclusion of $P$. cissicola NCPPB $2982^{\mathrm{T}}$ in group 6 along with $X$. campestris pv. campestris and $X$. maltophilia indicates that these bacteria are closely related. However, I obtained more strains in an attempt to substantiate this, and two strains (strains ICMP 4290 and ICMP 4291) produced profiles which contained no branched fatty acids but which were typical of Agrobacterium sp. (data not shown). However, 
TABLE 10. Comparison of groupings of Pseudomonas spp. determined in this study with groupings obtained in other studies

\begin{tabular}{|c|c|c|c|c|c|c|c|}
\hline Taxon & $\begin{array}{l}\text { Fatty acid group } \\
\text { or subgroup in } \\
\text { this study }\end{array}$ & $\begin{array}{l}\text { Fatty acid profile } \\
\text { group of Oyaizu } \\
\text { and Komagata }\end{array}$ & $\begin{array}{c}\text { RNA } \\
\text { homology } \\
\text { group }^{b}\end{array}$ & $\begin{array}{c}\text { rRNA } \\
\text { branch }^{c}\end{array}$ & $\begin{array}{c}\text { rRNA } \\
\text { branch }^{d}\end{array}$ & $\begin{array}{c}\text { Tyrosine } \\
\text { biosynthesis } \\
\text { group }\end{array}$ & $\begin{array}{l}\text { DAHP } \\
\text { group } f\end{array}$ \\
\hline$P$. aeruginosa & $1 \mathbf{a}$ & I & I & 1 & & & \\
\hline$P$. agarici & 1a & & & & 1 & I & I \\
\hline P. asplenii & $1 \mathrm{a}$ & & & & 1 & I & I \\
\hline$P$. aureofaciens & la & I & I & 1 & & I & I \\
\hline P. caricapapayae & la & & & & 1 & & \\
\hline P. chlororaphis & $1 \mathrm{a}$ & I & I & 1 & & I & I \\
\hline P. cichorii & la & & I & 1 & 1 & I & I \\
\hline P. ficuserectae & 1a & & & & & & \\
\hline$P$. fluorescens & la & I & I & 1 & 1 & I & \\
\hline P. fuscovaginae & $1 \mathrm{a}$ & & & & 1 & & \\
\hline "P. gingeri" & la & & & & & & \\
\hline P. marginalis & 1a & & & & 1 & I & \\
\hline P. meliae & $1 \mathrm{a}$ & & & & 1 & & \\
\hline$P$. putida & la & I & I & 1 & & I & \\
\hline "P. reactans" & 1a & & & & & & \\
\hline$P$. syringae & $1 \mathrm{a}$ & & I & 1 & 1 & I & I \\
\hline$P$. tolaasii & 1a & & & & 1 & & \\
\hline$P$. viridiflava & 1a & & I & & 1 & & \\
\hline $\begin{array}{l}P . \text { corrugata } \\
P \text { rubrisubalbicans }\end{array}$ & $1 b$ & & & & 1 & & \\
\hline $\begin{array}{l}P . \text { rubrisubalbicans } \\
P \text { alcaligenes }\end{array}$ & 1c & & & & 2 & & 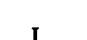 \\
\hline $\begin{array}{l}P . \text { alcaligenes } \\
P \text {. pseudoalcaligenes subsp. }\end{array}$ & $1 d$ & I & I & 1 & & I & 1 \\
\hline $\begin{array}{l}\text { P. pseudoalcaligenes subsp. } \\
\text { pseudoalcaligenes }\end{array}$ & $1 d$ & & 1 & & & & \\
\hline P. stutzeri & $1 d$ & I & I & 1 & & I & \\
\hline P. amygdali & 1e & & & & 1 & & \\
\hline$P$. cattleyae & If & & & & 1 & & \\
\hline P. andropogonis & $2 a$ & & & & 2 & III & III \\
\hline P. caryophylli & $2 a$ & & II & 2 & 2 & II & II \\
\hline P. cepacia & $2 a$ & & II & 2 & 2 & II & II \\
\hline$P$. gladioli & $2 a$ & II & II & 2 & 2 & II & II \\
\hline P. plantarii & $2 a$ & & & & & & \\
\hline P. glumae GC subgroup A & $2 a$ & & & & 2 & & \\
\hline$P$. glumae GC subgroup $\mathrm{B}$ & $2 b$ & & & & 2 & & \\
\hline$P$. solanacearum & $2 \mathrm{c}$ & & II & 2 & 2 & II & \\
\hline P. syzygii & $2 \mathrm{c}$ & & & & & & \\
\hline Banana blood disease bacterium & $2 \mathrm{c}$ & & & & & & \\
\hline C. acidovorans & $3 \mathbf{a}$ & III & III & 3 & 3 & III & III \\
\hline P. avenae & $3 \mathbf{a}$ & IX & & & 3 & III & III \\
\hline$P$. cattleyae (type strain) & $3 a$ & & & & 3 & & \\
\hline$P$. pseudoalcaligenes subsp. citrulli & $3 a$ & & & & 3 & & \\
\hline P. pseudoalcaligenes subsp. konjaci & $3 \mathrm{a}$ & & & & & & \\
\hline P. rubrilineans & $3 a$ & & & & 3 & III & \\
\hline C. testosteroni & $3 \mathrm{~b}$ & III & III & 3 & 3 & & \\
\hline S. paucimobilis & 4 & VI & & & & & \\
\hline$P$. flectens & 5 & & & & $?$ & & \\
\hline P. betle & 6 & & & & 4 & & \\
\hline P. cissicola & 6 & & & & $?$ & & \\
\hline P. hibiscicola & 6 & & & & 4 & $?$ & $\mathrm{~V}$ \\
\hline$X$. maltophilia & 6 & IV & V & 4 & & V & V \\
\hline$X$. campestris pv. campestris & 6 & & V & & 4 & V & $\mathrm{V}$ \\
\hline
\end{tabular}

a See reference 16.

${ }^{b}$ See reference 19.

${ }^{c}$ See reference 4 .

${ }^{d}$ See reference 5. 1, P. fluorescens rRNA branch; 2, P. solanacearum rRNA branch; 3, C. acidovorans rRNA branch; 4 , Xanthomonas rRNA branch.

${ }^{e}$ See reference 2 .

$f$ See reference 32. DAHP, 3-deoxy-D-arabinoheptulosonic acid 7-phosphate.

strain ICMP $8561^{\mathrm{T}}$ had a profile that was very similar to that of strain NCPPB $2982^{\mathrm{T}}$. The original ICMP type strain, strain ICMP 4289, was replaced in 1977 by type strain ICMP 8561, which was also derived from the original strain $\mathrm{PC1}$ culture obtained from M. Goto. Thus, of the three Goto strains available, only the type strains (strains NCPPB 2982 and ICMP 8561) had profiles containing branched fatty acids. The true taxonomic position of the other two strains will require further study. Since the fatty acid profiles of the $X$. campestris pv. campestris and $X$. maltophilia strains used in this study are typical of all other Xanthomonas spp. and $X$. campestris pathovars, it is highly likely that $P$. betle, $P$. hibiscola, and $P$. cissicola NCPPB $2982^{T}$ also belong to the genus Xanthomonas. All contain three hydroxy fatty acids (12:0 3-OH, 11:0 iso 3-OH, and 13:0 iso 3-OH). No bacteria other than those included in this study or included in the 
genus Xanthomonas are known to contain these three hydroxy fatty acids (unpublished data). Branched, hydroxy fatty acids are not common in bacteria. However, some members of the Cytophaga-Flavobacterium complex contain $15: 0$ iso $3-\mathrm{OH}$ and $17: 0$ iso $3-\mathrm{OH}$ along with a large percentage of branched nonhydroxy fatty acids, as in the genus Xanthomonas (unpublished data). It is interesting that members of both genera are yellow-pigmented bacteria that often reside on the surfaces of plants. Palleroni (17) has suggested that $P$. hibiscicola is synonymous with $X$. maltophilia. Bradbury (1) cited DNA-rRNA homology studies which also indicated that $P$. betle is a Xanthomonas sp. These results also support the transfer of $P$. maltophilia to the genus Xanthomonas as $X$. maltophilia (29). It has long been known that $P$. maltophilia contains branched fatty acids (12). Thus, group 6 strains fell into three profile types representing $P$. cissicola, $X$. campestris pv. campestris, and $X$. maltophilia. The latter could not be differentiated from $P$. hibiscicola and $P$. betle, but was readily differentiated from $X$. campestris pv. campestris by the amounts of 14:0, 15:0 iso, $16: 1$ cis $9,16: 0,17: 1$ iso $F$, and 17:0 iso. There were no major qualitative differences between the profiles of $P$. cissicola and the other xanthomonads, but these profiles were readily differentiated by the amounts of 10:0 $3-\mathrm{OH}$, 12:0 3-OH, 15:0 anteiso, and 16:1 cis 9.

Comparison of groupings based on fatty acid profiles with groupings based on the results of other techniques. Several taxonomic studies on pseudomonads have been carried out recently $(2,4,5,7,16,18,19,32)$. There is generally good correlation among the groupings made on the basis of these techniques, including DNA-DNA and DNA-rRNA hybridization studies $(4,5,7,17,18,24)$, enzyme studies $(2,32)$, and another fatty acid profiling study (16). Table 10 compares the groups based on fatty acid profiles with the groups based on the results of the techniques mentioned above.

DNA-DNA and DNA-rRNA groupings. There was excellent correlation between groupings based on the results of DNADNA and DNA-rRNA techniques and groupings based on fatty acid profiles. Four major rRNA groups within the genus Pseudomonas have been proposed (17). These groups center around four species, $P$. aeruginosa, $P$. solanacearum, $C$. acidovorans, and $X$. maltophilia. The groups based on fatty acid profiles were identical to the nucleic acid homology groups in all but one case. $P$. nubrisubalbicans was placed in rRNA group II with $P$. solanacearum (5); fatty acid profiling indicated much closer similarity to taxa included in rRNA group I.

There was also agreement that the type strain of $P$. cattleyae is closely related to $C$. acidovorans, whereas the other strain available (strain NCPPB 1874) is closely related to $P$. fluorescens (5). Whereas $P$. pseudoalcaligenes subsp. pseudoalcaligenes belongs to fatty acid group $1, P$. pseudoalcaligenes subsp. citrulli and $P$. pseudoalcaligenes subsp. konjaci do not. They belong to fatty acid group 3 along with $C$. acidovorans and $P$. avenae.

The results of the fatty acid study also indicated that there are subgroups within groups 1,2 , and 3 . For group 2 there was a good correlation with DNA-DNA hybridization subgroups (17).

Enzyme studies. Several different enzyme systems have been used to group pseudomonads $(2,32)$. Again there was good correlation (Table 10) between the groups based on the results of enzyme studies and the groups based on fatty acid profiles. One exception was $P$. andropogonis, which was placed in group 2 in this study but in the acidovorans group on the basis of the results of enzymological patterning in tyrosine biosynthesis (2) and comparative allostery of 3-deoxy-D-arabino-heptulosonate-7-phosphate synthetase (32). DNA-rRNA hybridization studies (5) placed $P$. andropogonis in rRNA group II along with $P$. caryophylli and $P$. solanacearum, as in this study.

Other fatty acid profile studies. The importance of fatty acid profiles in classification and rapid identification of some Pseudomonas spp. has been recognized for some time (8-13, $16,23,24,26)$. A few plant-pathogenic species were included in two previous studies $(16,26)$. One of these studies $(16)$ also compared groups based on fatty acid profiles with rRNA groups and showed fairly good correlation between them. The results also parallelled those presented here except for both strains of $P$. avenae, which were placed in a separate group. In my study all $P$. avenae strains belonged to group 3 along with $C$. acidovorans and $C$. testosteroni. Oyaizu and Komagata (16) used a different method of saponification and methylation; they also separated some FAMEs by thin-layer chromatography. Although these authors obtained the same FAMEs in their profiles, no quantitative comparison could be made. They placed great emphasis on the value of 3 -hydroxy acids in grouping pseudomonads. My results also showed the value of 2 -hydroxy acids. This emphasizes the need for standardization of the methods used for saponification, methylation, and extraction of the fatty acids.

Thus, apart from a few differences in grouping between the results of fatty acid profiling and the results of other techniques reported previously, there was generally excellent agreement.

In a future paper I will look at the potential of fatty acid profiling for rapid, accurate identification of the same group of bacteria by using a commercially available computerized pattern recognition algorithm to compare individual profiles with libraries of profiles derived from a range of strains for each taxon.

\section{ACKNOWLEDGMENTS}

I thank J. Sellwood, J. Wilson, C. Woodruff, D. Smith, P. Hubbard, C. Dalby, and L. Adepoju for excellent technical assistance. J. Wilkins kindly provided mass spectrometric data. I also thank M. Sasser (Microbial ID, Inc.) and M. Roy for expert advice, technical support, and above all encouragement. I am grateful to the following people for providing strains: T. Fermor (Horticulture Research International, Littlehampton, United Kingdom); I. Harris (Royal Holloway and New College, London, United Kingdom); S. Roberts and J. Taylor (Horticulture Research International, Wellesbourne, United Kingdom); S. Eden Green (Institute of Arable Crop Research, Rothamsted, Harpenden, United Kingdom); J. Neto (Instituto Biologico, Campinas, Brazil); and J. Young (International Collection of Microorganisms from Plants, Auckland, New Zealand).

This work was funded by the Ministry of Agriculture, Fisheries and Food and was included in Research and Development Project PH14000.

\section{REFERENCES}

1. Bradbury, J. F. 1987. Guide to plant pathogenic bacteria. Commonwealth Agricultural Bureaux. International Mycological Institute, Wallingford, United Kingdom.

2. Byng, G. S., R. J. Whitaker, R. L. Gherna, and R. A. Jensen. 1980. Variable enzymological patterning in tyrosine biosynthesis as a means of determining natural relatedness among the Pseudomonadaceae. J. Bacteriol. 144:247-257.

3. Claflin, L. E., and B. A. Ramundo. 1987. Synonymy of Pseudomonas avenae Manns 1905, and Pseudomonas rubrilineans Lee et al. 1925. Phytopathology 77:1766.

4. De Vos, P., and J. De Ley. 1983. Intra- and intergeneric similarities of Pseudomonas and Xanthomonas ribosomal ribo- 
nucleic acid cistrons. Int. J. Syst. Bacteriol. 33:487-509.

5. De Vos, P., M. Goor, M. Gillis, and J. De Ley. 1985. Ribosomal ribonucleic acid cistron similarities of phytopathogenic Pseudomonas species. Int. J. Syst. Bacteriol. 35:169-184.

6. De Vos, P., K. Kersters, E. Falsen, B. Pot, M. Gillis, P. Segers, and J. De Ley. 1985. Comamonas Davis and Park 1962 gen. nov. rev. emend., and Comamonas terrigena Hugh 1962 sp. nov., nom. rev. Int. J. Syst. Bacteriol. 35:443-453.

7. De Vos, P., A. Van Landschoot, P. Seghers, R. Tytgat, M. Gillis, M. Bauwens, R. Rossau, M. Goor, B. Pot, K. Kersters, P. Lizzaraga, and J. De Ley. 1989. Genotypic relationships and taxonomic localization of unclassified Pseudomonas and Pseudomonas-like strains by deoxy-ribonucleic acid-ribosomal ribonucleic acid hybridizations. Int. J. Syst. Bacteriol. 39:35-49.

8. Ikemoto, S., H. Kuraishi, K. Komagata, R. Ajuma, T. Suto, and H. Murooka. 1978. Cellular fatty acid composition in Pseudomonas species. J. Gen. Appl. Microbiol. 24:199-213.

9. Moss, C. W. 1981. Gas-liquid chromatography as an analytical tool in microbiology. J. Chromatogr. 203:337-347.

10. Moss, C. W., S. B. Dees, and G. O. Guerrant. 1980. Gas-liquid chromatography of bacterial fatty acids with a fused-silica capillary column. J. Clin. Microbiol. 12:127-130.

11. Moss, C. W., M. A. Lambert, and W. H. Mervin. 1974. Comparison of rapid methods for analysis of bacterial fatty acids. Appl. Microbiol. 28:80-85.

12. Moss, C. W., S. B. Samuels, J. Liddle, and R. M. McKinney. 1973. Occurrence of branched-chain hydroxy fatty acids in Pseudomonas maltophilia. J. Bacteriol. 114:1018-1024.

13. Moss, C. W., S. B. Samuels, and R. E. Weaver. 1972. Cellular fatty acid composition of selected Pseudomonas species. Appl. Microbiol. 24:596-598.

14. Nishiyama, K., T. Kusaba, K. Ohta, K. Nahata, and A. Ezuka. 1979. Bacterial black spot of tulip caused by Pseudomonas andropogonis. Ann. Phytopathol. Soc. Jpn. 45:668-674.

15. Owen, R. J., and P. J. H. Jackman. 1982. The similarities between Pseudomonas paucimobilis and allied bacteria derived from analysis of deoxyribonucleic acids and electrophoretic protein patterns. J. Gen. Microbiol. 128:2945-2954.

16. Oyaizu, H., and K. Komagata. 1983. Grouping of Pseudomonas species on the basis of cellular fatty acid composition and the quinone system with special reference to the existence of 3-hydroxy fatty acids. J. Gen. Appl. Microbiol. 29:17-40.

17. Palleroni, N. J. 1984. Genus I. Pseudomonas, p. 141-199. In N. R. Krieg and J. G. Holt (ed.), Bergey's manual of systematic bacteriology, vol. 1. The Williams \& Wilkins Co., Baltimore.

18. Palleroni, N. J., R. W. Ballard, E. Ralston, and M. Doudoroff. 1972. Deoxyribonucleic acid homologies among some Pseudomonas species. J. Bacteriol. 110:1-11.

19. Palleroni, N. J., R. Kunisawa, R. Contopoulou, and N. Doudoroff. 1973. Nucleic acid homologies in the genus Pseudomonas. Int. J. Syst. Bacteriol. 23:333-339.

20. Ramundo, B. A., and L. E. Claflin. 1990. Demonstration of synonymy between the plant pathogens Pseudomonas avenae and Pseudomonas rubrilineans. J. Gen. Microbiol. 136:2029 2033.

21. Ratledge, C., and S. G. Wilkinson (ed.). 1988. Microbial lipids, vol. 1. Academic Press, London.

22. Roberts, S. J., S. J. Eden-Green, P. Jones, and D. J. Ambler. 1990. Pseudomonas syzygii sp. nov., the cause of Sumatra disease of cloves. Syst. Appl. Microbiol. 13:34-43.

23. Roy, M. A. 1988. Use of fatty acids for the identification of phytopathogenic bacteria. Plant Dis. 72:460.

24. Sasser, M., and D. H. Smith. 1987. Parallels between ribosomal RNA and DNA homologies and fatty acid composition in Pseudomonas, p. 241. Abstr. 87th Annu. Meet. Am. Soc. Microbiol. 1987. American Society for Microbiology, Washington, D.C.

25. Skerman, V. B. D., V. McGowan, and P. H. A. Sneath (ed.). 1980. Approved lists of bacterial names. Int. J. Syst. Bacteriol. 30:225-420.

26. Stead, D. E. 1988. Identification of bacteria by computerassisted fatty acid profiling. Acta Hortic. (The Hague) 225:3946.

27. Stead, D. E. 1989. Grouping of Xanthomonas campestris pathovars of cereals and grasses by fatty acid profiling. EPPO (Eur. Mediterr. Plant Prot. Organ.) Bull. 19:57-68.

28. Stead, D. E. Techniques for detecting and identifying plant pathogenic bacteria. In J. M. Duncan and L. Torrance (ed.), Techniques for the rapid detection of plant pathogens, in press. Blackwell Scientific Publications, Oxford.

29. Swings, J., P. De Vos, M. Van den Mooter, and J. De Ley. 1983. Transfer of Pseudomonas maltophilia Hugh 1981 to the genus Xanthomonas as Xanthomonas maltophilia (Hugh 1981) comb. nov. Int. J. Syst. Bacteriol. 33:409-413.

30. Tamaoka, J., D. M. Ha, and K. Komagata. 1987. Reclassification of Pseudomonas acidovorans den Dooren de Jong 1928 and Pseudomonas testosteroni Marcus and Talalay 1956 as Comamonas acidovorans comb. nov., with an amended description of the genus Comamonas. Int. J. Syst. Bacteriol. 37:52-59.

31. Van Bruggen, A. H. C., K. N. Jochimsen, and P. R. Brown. 1990. Rhizomonas suberifaciens gen. nov., sp. nov., the causal agent of corky root of lettuce. Int. J. Syst. Bacteriol. 40:175-188.

32. Whitaker, R. J., G. S. Byng, R. L. Gherna, and R. A. Jensen. 1981. Comparative allostery of 3-deoxy-D-arabino-heptulosonate-7-phosphate synthetase as an indicator of taxonomic relatedness in pseudomonad genera. J. Bacteriol. 145:752-759.

33. Willems, A., J. De Ley, M. Gillis, and K. Kersters. 1991. Comamonadaceae, a new family encompassing the acidovorans rRNA complex, including Variovarax paradoxus gen. nov., comb, nov., for Alcaligenes paradoxus (Davis 1969). Int. J. Syst. Bacteriol. 41:445-450.

34. Willems, A., B. Pot, E. Falsen, P. Vandamme, M. Gillis, K. Kersters, and J. De Ley. 1991. Polyphasic taxonomic study of the emended genus Comamonas: relationship to Aquaspirillum aquaticum, E. Falsen group 10, and other clinical isolates. Int. J. Syst. Bacteriol. 41:427-444.

35. Yabuuchi, E., I. Yano, H. Oyaizu, Y. Hashimoto, T. Ezaki, and H. Yamamoto. 1990. Proposals of Sphingomonas paucimobilis gen. nov. and comb. nov., Sphingomonas parapaucimobilis $\mathrm{sp}$. nov., Sphingomonas capsulata comb. nov., and two genospecies of the genus Sphingomonas. Microbiol. Immunol. 34:99 119. 